\title{
What is Visual Knowledge, and What is it Good for? Potential Ethnographic Lessons from the Field of Legal Practice
}

Richard Sherwin

New York Law School, richard.sherwin@nyls.edu

Neal Feingenson

Christina Speisel

Follow this and additional works at: https://digitalcommons.nyls.edu/fac_articles_chapters

\section{Recommended Citation}

Sherwin, Richard; Feingenson, Neal; and Speisel, Christina, "What is Visual Knowledge, and What is it Good for? Potential Ethnographic Lessons from the Field of Legal Practice" (2007). Articles \& Chapters. 1145.

https://digitalcommons.nyls.edu/fac_articles_chapters/1145 


\title{
What Is Visual Knowledge, and What Is It Good for? Potential Ethnographic Lessons from the Field of Legal Practice
}

\author{
Richard K. Sherwin, Neal Feigenson, and Christina Spiesel
}

\begin{abstract}
A firm basis exists for an instructive exchange between anthropologists and legal scholars regarding the production, dissemination, and interpretation of visual meaning in this digital era. The practice and theory of law and anthropology today are increasingly being shaped and informed by what appears on electronic screensin the field, the workplace, and inside the classroom. Practicing lawyers and ethnographers need new tools of analysis and representation to meet the intellectual and aesthetic demands of digital visual rhetoric. This article offers a multidisciplinary approach to understanding the visual meaning-making process on the open source borderland between disciplinary expertise and pop cultural communication.
\end{abstract}

\section{VISUALS IN LAW AND ETHNOGRAPHY}

This essay ${ }^{1}$ is premised on the belief that a firm basis exists today for an instructive exchange between anthropologists and legal scholars regarding the production, dissemination, and interpretation of visual meaning in the digital era.

In what follows, we want to emphasize a particular aspect of the integration of visuals into the professional practices of law and ethnography. Like any competent craftsperson, professionals in both fields are expected to understand and, when appropriate, control the meaning-making features of the communication tools that they choose to deploy. Each tool has virtues and drawbacks, and it is good to know what they are [Ruby 2000: 22; Elkins 2003: 97]. For example, visuals tend to amplify affective content by generating clusters of embodied associations in the mind of a viewer; as Murray-Brown points out;

RICHARD K. SHERwIN has written widely on the interrelationship between law and culture, including interdisciplinary works on law and visual communication, law and film, discourse theory, political legitimacy, and the emerging field of cultural legal studies. NeAL FeIGENson is Professor of Law at Quinnipiac University School of Law and a Research Affiliate in the Yale University Department of Psychology. Professor Feigenson's research interests include applications of social and cogntive psychology to legal decision making and the role of visual communication and rhetoric in law. CHRISTINA SPIESEL is an artist and writer who has been co-teaching Visual Persuasion in the Law to advanced law students since 2000 at Quinnipiac University School of Law and New York Law School. She is a Senior Research Scholar at Yale Law School. She has presented at meetings of the AALS, Law and Society, ASLCH, and the International Roundtable for the Semiotics of Law. E-mail: rsherwin@nyls.edu 
"The highest power of television journalism is not in the transmission of information but in the transmission of experience...joy, sorrow, shock, fear, these are the stuff of news" [1991: 32]. Such associations will be triggered by a variety of cognitive and experiential factors ranging from personal history to familiar social scripts, recognizable character types, and other unconsciously assimilated cultural referents and templates (which is to say, other forms of visual common sense) [Geertz 1983: 85]. Associations will also be cued by internal resonances that are set off by discrete filmmaking techniques-the shooting and editing process itself. If you think you are constructing a logical argument when you are really composing a poem or a musical score, which may be better analogues to film composition [MacDougall 1998: 84; Tyler 1986: 125], odds are you will be in control of neither your medium nor your message.

The requirement of visual literacy and craftsmanship may seem to be rather straightforward, but things are not that simple. Over the last few decades legal scholars, like a good number of their anthropological counterparts, have been struggling to work through a crisis of sorts regarding the nature and communicability of truth [Pink 2001: 1; Shweder 1991: 59]. This difficulty has been both eased and exacerbated by the unprecedented control over descriptive reality that digital communication technologies allow. The exquisite detail of a computergenerated image can quickly convey complex data. At the same time, however, computer technology has made it increasingly difficult to detect any discernible difference between a digital simulation of an event and its nonvirtual reality. (In some legal cases involving child pornography, for example, this difficulty has made it almost impossible for prosecutors to shoulder their burden of proof that the images in question are unlawful because real children were being used [Ashcroft $v$. The Free Speech Coalition 2002, United States of America v. David Hilton 2004, Weimann 2000: 330-335]). This issue goes to the heart of no less a matter than what counts as legitimate knowledge, and what gets discounted as unacceptable within a particular domain of professional fieldwork.

Once we step beyond this threshold matter, the next question is: How does a discipline police its boundaries? For lawyers, this query is hardly academic. Inside the courtroom, the difference between truth and falsity, fact and fantasy, objectivity and subjectivity may be a matter of life and death.

Before proceeding further, a few preliminary remarks about lawyers as fact gatherers, image users, and storytellers may be in order. We will then review shared concerns and challenges that lawyers and ethnographers face when visuals are incorporated into their respective professional practices. Next, we will pursue in some detail how visuals and the impact of visual digital communication technologies in particular are changing what now passes for conventional knowledge and practical skill sets in the contemporary practicing of ethnography and law.

Lawyers, like ethnographers, are often called upon to gather a wide variety of data from the field. Something has happened, a conflict has broken out, and now a contest looms over what it all means. What is its legal significance? The facts that lawyers seek and the tools they use to credibly convey the import and meaning of the facts depend in significant part on a lawyer's working legal theory for the particular case at hand. This means that at the outset the lawyer must identify

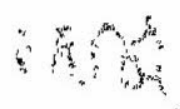


in what sector of the law's territory the case is located. Do the facts invoke penal laws, property laws or contract law? Or perhaps it will be a tort matter (which is to say, a civil lawsuit involving claims of personal injury or damage to personal property). Let's say the lawyer's client was injured in a car accident-a tort case. In this instance, there is a good chance that the rules of negligence will come into play. If so, the fact narrative will have to focus on such matters as whether the alleged wrongdoer's careless act caused the accident and ensuing harm or whether other forces were at work-forces beyond the actor's control. If the latter turns out to be the case, there would be no one to blame, and thus no basis to compel the alleged wrongdoer to pay damages.

In addition to locating the case on the map of substantive law, the lawyer also must consider a broad range of rhetorical moves. For example, is the narrative meant to inform and guide the judgment of a particular judge or a jury? If the former, there is likely to be a well-documented paper trail, the archive of that judge's prior decisions, which may be mined for ideological or idiosyncratic preferences. Each preference suggests ways to appeal to that particular judge's patterns of thought, including his or her normative and aesthetic inclinations. Of course, the lawyer may also choose a less strategically nuanced (or less self-reflexive) path by simply presenting the applicable legal rules and principles as the lawyer understands them. In any event, the fact narrative remains inescapably embedded within a larger, professional ("disciplined") discourse.

Every trial conducted within the Anglo-American, adversarial common law tradition involves competing reconstructions of reality. This means that each side must cobble together a compelling narrative out of discrete evidentiary fragments: eyewitness accounts, expert analyses of physical evidence, relevant documentation, and so on. In the end, lawyers will try to tell the most compelling narrative that the trial evidence will support concerning what happened and why. In order for outsiders (a juror, say, or a judge) to understand the persons and events involved, context, character, and motivation must be carefully evoked and construed. Along the way, numerous strategic decisions must be made: Where should the story begin? How should it be sequenced? Who are the main characters, and when should they be brought on stage? What genre and voice should be used [Sherwin 1988: 551]? Careful consideration also must be given to the audience: What role will they play? Should they be cast as detectives, helping the lawyer to solve the mystery of the case ("who done it")? Or perhaps they should be cast as heroes, joining in the lawyer's quest for justice [Sherwin 2004].

With so many narrative choices (where to begin, what to include, what to leave out) the resulting text is anything but natural. This implicates the rhetorical (or "constructivist") anxiety that underlies all cultural representation. As Clifford Geertz puts it, "if the fact-configurations are not merely things found lying about in the world and carried bodily into court, show-and-tell style, but close-edited diagrams of reality the matching process itself produces, the whole thing looks a bit like sleight-of-hand" [Geertz 1983: 173]. Of course, there are many ways for narrative to fail: when the artifice shows through too plainly, or when the generic frame lacks the power to make factual fragments cohere, or when the story to be told lacks a familiar enough generic template to meet the expectations an audience brings to the telling. In the face of defective narrative design, odds 
are that the audience's default sense of reality (their commonsense narrative schemata for this kind of person/event) will prevail [Sherwin 1994: 39]. This observation accords with James Clifford's disturbing account of Mashpee tribal members who unsuccessfully sought to establish their authenticity as Native Americans in a 1976 land claim suit. Ultimately the suit failed; the claimants in court just didn't look and sound enough like "real Indians." The benchmark for Mashpee identity had become too diffuse over long decades of cultural assimilation and resistance. Clifford cuts to the crux of the dilemma when he writes, "In the courtroom how could one give value to an undocumented 'tribal' life largely invisible (or unheard) in the surviving record?" [Clifford 1988: 338-339].

In litigation, the legal theory of the case determines the relevance and importance of facts. Similarly, by providing a benchmark for the innumerable decisions about inclusion and exclusion that need to be made in ethnographic fieldwork, theory also guides the search for cultural meaning-as Banks and Morphy point out: "[M]ethod in anthropology has to be recognized as inherently theoretical in its implications and it is today a requirement to make explicit these theoretical underpinnings" [1997: 13]. Of course, determining which theory should govern under what circumstances is a matter of some internal controversy. This controversy has been abetted by the introduction of visuals. So long as the function and goals of visual communication remain uncertain in practice and inadequately thought through in theory-which is to say, so long as professionals fail to appreciate the discrete kinds of knowledge and meaning making that their visual practices produce or invite - the greater the likelihood that rhetorical anxiety and professional disquiet will persist. Visuals resist conventional (text-based) interpretive coding. Their stubbornly open nature, what David MacDougall calls the visual image's "connotative" as opposed to text's "denotative" quality, adds uncertainty to the ethnographer's narrative choices [MacDougall 1998: 286]. Visuals also exhibit a tendency to privilege particular kinds of knowledge and ways of knowing above others. Of particular note in this regard is the sensual or embodied nature of visual knowledge [Pink 2006: 49]. The viewer tends to respond affectively to the "flesh" of the visual image and its characteristic stimulus toward associative or nonlinear thinking [Stoller 1997: 77].

In addition to these internal qualities of the visual, there are also external uncertainties concerning the viewer's interpretive uptake. As Morphy and Banks note, "One of the objectives of visual anthropology must be to reveal these different 'ways of seeing' within and between societies and to show how they influence action in the world and people's conceptualizations of the world" [1997: 22]. Visual rhetoric always raises questions of interpretive access, such as: From whose point of view are we supposed to be viewing what we see on the screen [MacDougall 1998: 77]? The camera is placed here and not there; the scene begins at this point and ends at that one; the editor places this scene or image next to that one. How then are we to conclude that the end product may properly be viewed as local knowledge as opposed to local knowledge fused with professional ethnographic interpretation? And how are we supposed to know which is which? In short, the familiar reflexivity issue is rhetorically amplified by the "sleight-of-hand" characteristic of realistic appearances on the screen.

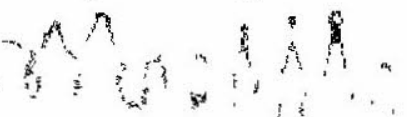


How does one facilitate a "local frame of awareness" [Geertz 1983: 6] when the interpretive mediation that informs the filmmaker's-or, for that matter, the viewer's - (preconscious) visual commonsense operates substantially differently from the meaning-making frame that shapes and informs the indigenous subject's local knowledge? As Jennifer Deger has brilliantly shown, film can be used to reflect the values and,aesthetic concerns : of an indigenous cultural imaginary [Deger 2007]. When this occurs; . visual images constitute a discrete form of experience. To share this experience, one must open oneself up to the visual flow-just as one might immerse oneself in a musical or theatrical performance. In short, the phenomenology of perception operates as an antecedent to a more reflexive analytical process. :

Of course there is something of a double bind at work here. Without at least a threshold appreciation of what Deger calls the "cultural protocols" and "epistemological imperatives" of the visual display, the viewer may fail to experience the work at all. On the other hand, set in too reflexive a posture, the critical observer, intent on detached analysis, may remain foreclosed from experiencing the mimetic reality that the visual may offer. To meet this interpretive challenge requires an agile and informed interactivity. This involves a multimodal process of immersion followed by critical analysis in which the viewer's own perceptions, affects, and perhaps even spiritual insights become part of the interpretive process. Simply put, the visual teaches us to think with the body.:

Today we face new issues and new challenges associated with the rise of digital communication and the proliferation of visual mass media. Visual images offer an immediacy of access to trained as well as untrained eyes. With the help of visual images, previously hidden physical details may be brought into plain sight: the way chemicals seeped into nearby ground-water, the way a defective tail wing caused an airplane to crash, or how ammonia molecules were deliberately used by cigarette manufacturers to deliver nicotine more effectively. Yet, precisely because of their ease of access and credibility ("seeing is believing") visual images introduce new challenges. Consider; for example, a criminal trial in which a home video depicting police officers surrounding and beating a lone civilian is digitally replotted to "demonstrate" how the civilian's movements "caused" the police to beat him. When the news televised George Holiday's images of a group of white Los Angeles police officers repeatedly striking black motorist Rodney King with their batons, public sympathy for King was strong. What could justify that kind of concerted violence against an unarmed civilian?

Indeed, the prosecutor in the state criminal case against the officers seemed to echo this popular sentiment. "Just watch the videotape," he repeatedly told the jurors. But his trust in the simplicity of visual truth turned out to be misplaced. Locked into his own naïve realist perspective, the prosecutor never paused to consider the persuasive impact on the jurors of the defense's strategy. By digitizing Holliday's images, defense lawyers gained significant control over the representation and renarratization of what the jurors saw on the screen at the trial. By slowing down and isolating specific visual frames, the defense defused the violence of the police blows [Feldman 1996; Goodwin 2001: 174-178]. Even more importantly, however, by altering the sequential flow of the images, the defense team managed to reverse causation in the jurors' minds. The premise 
was simple. Psychologists have long known that when we see two objects come together and one immediately moves away our mind reads causation into the scene. It looks as if one object caused the other to move. Similarly, when jurors watched the digital version of George Holliday's videotape, first they saw Rodney King's body rise off the ground (in direct violation of the officers' instructions), then they saw the officers' batons come down on his body. When King resumed the prone position, the police batons rose up again. And so the pattern continued, with King rising up and batons coming down. In short, the defense had effectively renarrated the scene to establish that King's own movements had caused the batons to strike him. Instead of the prosecutor's story about white, racist cops beating an innocent, black motorist, jurors now "saw" a series of images in which police officers carefully (and professionally) "escalated and deescalated" levels of force in direct response to King's aggressive resistance of arrest.

Or consider the case in which a closing argument was presented in court entirely on video. It was a civil dispute involving the largest accounting firm in the world, Price Waterhouse. In arguing their case, the plaintiff's lawyers used a visual montage showing a broad range of visual images, borrowing from both documentary and feature film sources. The central image, however, remained the same throughout. There on the screen was the unsinkable Titanic, the largest ocean-going vessel in the world in its time. Why the Titanic? The plaintiff's case theory was as simple as it was ingenious. Price Waterhouse had been hired to investigate the financial standing of a bank that the plaintiff wanted to take over. In the course of their analysis, however, Price Waterhouse made numerous accounting errors, and their carelessness caused the plaintiff to unwittingly take on massive unsecured loans. The upshot? Price Waterhouse might be the largest accounting firm in the world-but, just like the Titanic, being the largest is no guarantee against carelessness and disaster. That the plaintiffs' legal team indiscriminately mingled documentary and feature film images of the Titanic and its tragic fate left the trial judge unfazed. Defense objections at the trial were overruled (though this ruling was later reversed on appeal) [Feldman 1996; Goodwin 2001: 174-1781.

As electronic screens have proliferated, our minds have rapidly adapted. We have learned to view multiple "windows" onto the real and the virtual simultaneously; we have come to accept simulations interspersed with real-life documentation; and we have willingly absorbed narratives with fragmented timelines shaped by nonlinear ("associative") forms of logic that flaunt self-reflexive allusions to the interpretive process of meaning-making itself. As Steven Johnson has observed, video games, films, and popular television shows have grown more complex over time [Johnson 2005]. According to Johnson, consumers are drawn specifically to those products that require the most mental engagement, from small children who can't get enough of their favorite Disney DVDs to adults who find new layers of meaning with each repeated viewing of the comedy television series Seinfeld. Indeed, increasingly sophisticated viewing habits are required to make sense of the multiple networks of characters and subplots that are commonly featured on popular television shows. Fast-moving, interactive video games require increasingly sophisticated adaptive responses to

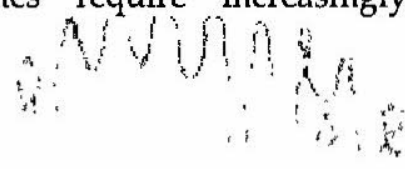


problem-solving. Similarly, a discrete cognitive acuity is also required to appreciate such films as Quentin Tarantino's' Pulp Fiction [1994], a work that invites viewers to develop not only cognitive associations that connect its nonlinear (starkly nonchronological) sequence of scenes, but also external associations to other films that add layers of meaning to the screen experience. In short, human perception and cognition are rapidly adapting to the nature and demands of new communication technologies.

As a matter of everyday practice, in courtrooms across America legal and nonlegal realities are being projected visually in a variety of ways inside the courtroom-from "day in the life" documentaries in personal injury lawsuits to reality-based police surveillance and security videos, amateur and news journalist videos (together with their digitized reconstruction), computer graphics and digitally reconstructed accidents and crime reenactments, and video montage as a form of legal argumentation (including the interweaving of documentary and feature-film images, as occurred in the "Titanic" closing argument). The blurring of Hollywood fictions and legal reality is also occurring in the stories trial lawyers tell. Consider the prosecutors in real homicide cases who compare the accused to film characters from Francis Ford Coppola's The Godfather or Oliver Stone's Natural Born Killers, or the state's attorney who establishes a "knowing and voluntary" waiver of "Miranda. rights" based on the defendant's familiarity with a popular TV show [Kemple 1995: 1]."

For decades now it has been generally understood in the realm of the human sciences [Ricoeur 1981: 49] that interpretations of truth and falsity and judgments of liability and guilt are socially constructed and, to a significant degree, culturally contingent [Black 1962; Ricoeur 1981: 43]. Many other disciplines--including the philosophy of science' [Latour '1999], the philosophy of language [Austin 1962; Wittgenstein 1958], and linguistics [Sweetser 1990]-also recognize that meaning depends on context and that truth depends on the ways in which it is represented. Indeed, new studies of the physiology of perception indicate that even our most basic contacts with reality are socially mediated and constructed [Berns et al. 2005]. In short, across many disciplines, scholars have sought to explain how knowledge is locally constructed : through culturally embedded practices [Geertz 1983; Latour 1987; Latour and Woolgar 1987; Shweder 1991], and through diverse techniques of investigation and representation [Galison 1997; Hacking 1983]. So too in Anglo-American legal studies, many have recognized that legal meaning is produced by the ways law is practiced [Llewellyn 1960], and that rhetoric in its many guises is constitutive of, not opposed to, truth [Sherwin 1988, 1994].

Nevertheless, the cultural shift from an objectivist to a constructivist approach to human knowledge has not been anxiety-free [Bernstein 1985]: Many participants in and observers of the legal system in particular continue to experience uneasiness with the semioticians' wisdom that "it's all signs" [Sebeok 1994]. Their fear seems to be that embracing this constructivist insight would undercut confidence in the capacity of legal proceedings (paradigmatically, trials) to yield provable truths about the world [Burns 1999; Nesson 1985]. An unbridgeable gap between what legal decision-makers believe they need to know and what, on reflection, they seem able to know is for many a cause for real concern. Within 
this late modern (or postmodern) mindset, there is a heightened sense of inhabiting a universe of representations that seems to turn the urge for real-world knowledge back upon itself, as if in an endless regression, like some spectacular baroque tapestry or infinite arabesque endlessly folding in on itself [Sherwin 2005: 126; Wolfflin 1964: 34; Deleuze 1993: 3]. The notion that we live in a universe of endless representations is experienced by some not as a source of anxiety but as an opportunity for freedom and self-realization. As Flusser observes, "What the cultural revolution now under way is all about is that we have gained the ability to set alternative worlds alongside the one taken by us as given" [Flusser 1999: 65]. Lifton characterizes the shift toward fluidity and many-sidedness as an unconscious adaptation "to the restlessness and flux of our time" [Lifton 1999: 1].

This vertiginous sense of a lack of grounding has intensified in the digital age. Digital technologies allow the pictures and words from which meanings are composed to be seamlessly modified and recombined in any fashion whatsoever, while the Internet allows practically anyone, anywhere, to disseminate meanings just about everywhere. The Enlightenment-era insistence on essentialist foundations (whether exemplified by Locke's empiricism, Kant's rational categories, or other totalizing epistemologies) is being challenged by digital experience, which has helped to inspire an alternative model of knowledge and reality as a centerless and constantly morphing network of relations [Rorty 2004].

The task lawyers and, we venture to add, anthropologists face is to make sense of their respective practices in this nonessentialist, screen-dominated, and pervasively visual digital era. How are we to make peace with a rhetorical, constructivist approach to truth that tells us that representations can thoroughly mediate knowledge without seeming to dissolve that knowledge into mere adversarial contentions? (The split between "true" knowledge--as the product of universal reason or essentialist categories-and "mere" eloquence-as the historically contingent offshoot of the art of persuasion or digital aesthetics-recapitulates the perennial quarrel between ancients and moderns, which is to say, between the scientific rationality of philosophical dialectics and the techné or craft of rhetoric [Struever 1970: 5-39; Goodrich 1987; 97; Smith 1988: 183].)

Securing this realization makes way for the next query, one that typifies a more self-reflexively constitutive outlook: namely, what kinds of knowledge and meaning are created, and with what outcomes, when they are visually and digitally constructed in particular ways [White 1984: 266]?

Many practicing lawyers are already deeply engaged by these questions. They have to be. Lawyers know that winning cases means persuading their audiences to believe in their stories of what happened and their understandings of the legal significance of particular events and actions. They also know that to be successful they must understand the tools of communication at their (and their adversaries') disposal-in particular, the visual and multimedia tools that digital technologies provide. In short, trial lawyers, in order to be effective, must comprehend the effects that their rhetorical tools can have on audiences' perceptions, thoughts, and emotions. Law teachers, on the other hand, are only gradually catching on to the range of implications flowing from the ensuing changes in mind, culture, and technology [Courtroom 21 Project, http://www.wm.edu/ 
law/courtroom21/; Hirsh and Miller 2004]. Legal theorists too have been slow to grapple in a focused and systematic way with the new realities of law in the digital age.

In what follows, aside from simply flagging these epistemological issues, we would like to illustrate how they arise in legal practice.

Consider, for example, some scenes from contemporary legal practice.

- In a recent class action suit against some of the world's largest tobacco companies, the plaintiffs' lawyers contended that the defendant companies were being deceitful when they denied knowledge of the addicting properties of nicotine. At the trial a simple computer simulation demonstrated how ammonia molecules had been added to cigarettes for the sole purpose of facilitating the rapid intake of nicotine. The color-coded images made plain that the tobacco companies had designed their product as a maximally efficient nicotine delivery system [Figures 1 and 2].

- In its highly publicized 2002 prosecution of Michael Skakel for the 1975 murder of Martha Moxley, lawyers for the State of Connecticut used an interactive CDROM to display all of their demonstrative evidence throughout the trial, including photographs of the neighborhood and crime scene, diagrams of the locations at which real evidence had been found, and an audiotape of a telephone interview Skakel had given to a journalist in the late 1990s. During the closing argument, the prosecution replayed excerpts from the audiotape and simultaneously projected a transcript of Skakel's words onto a screen for jurors to follow. In the closing's most dramatic moment, jurors heard Skakel describe the panic he felt when Martha's mother asked him about her daughter the morning after the night of the murder-and simultaneously saw on the screen a photograph of Martha's lifeless body next to the transcript of Skakel's words [Connecticut v. Skakel] 2002; Carney and Feigenson 2004].

- For an insider trading case against the investment firm Kidder, Peabody and its former executive and corporate takeover wizard Martin Siegel, lawyers for the plaintiff Maxus Corporation (which eventually purchased the target company)

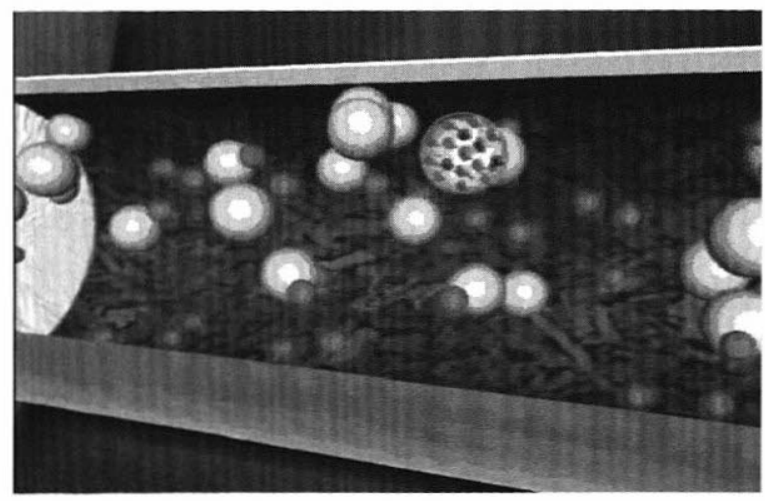

Figure 1 Color-coded graphic (reproduced here in black and white) used in litigation against tobacco companies, showing ammonia molecule facilitating delivery of nicotine in a cigarette (courtesy of LVS). 


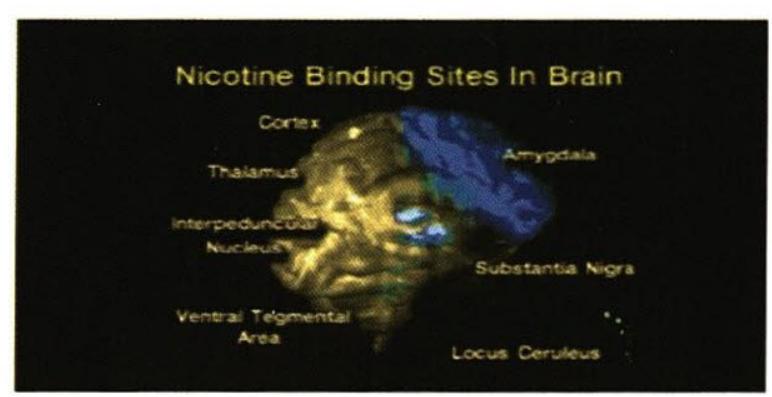

Figure 2 Graphic in tobacco litigation showing jurors how nicotine is absorbed in binding sites in the brain (courtesy of LVS).

prepared a closing argument video that incorporated animated graphics, archival photographs, excerpts from videotaped depositions, and other materials to show that Siegel had conspired with Ivan Boesky to drive up the target's stock price. Siegel's repeated refusal to testify at his depositions-he took the Fifth Amendment more than 600 times - was captured by nine sequential clips of Siegel looking down at a prepared text. As one clip followed another on the screen, they assumed the shape of a three-by-three grid reminiscent of the popular TV game show "The Hollywood Squares." When the grid was complete, the audience both saw and heard the simultaneous Siegels is turning the Fifth Amendment right to refuse to testify into a self-protective mantra [Figure 3; Stachenfeld and Nicholson 1996; Eichenwad 1992].

Lawyers, as rhetoricians, have always known that effective persuasion requires speaking in terms their audiences understand. And they are now adapting to a culture in which audiences are accustomed by their everyday work and leisure experiences with television, movies, print media, and computers to rely on visual - as well as audio and print-based - information. Adding to their traditional

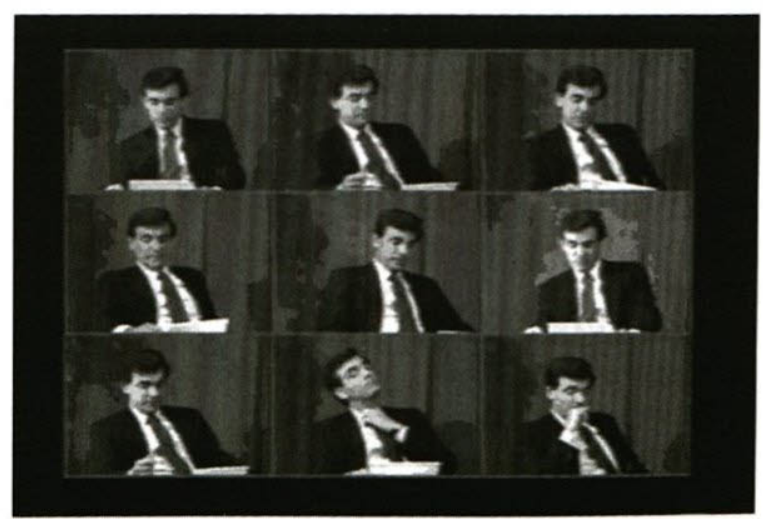

Figure 3 Graphic from insider trading case associating defendant's exercise of his Fifth Amendment privilege against compelled self-incrimination with a popular TV game show (courtesy of LVS). 


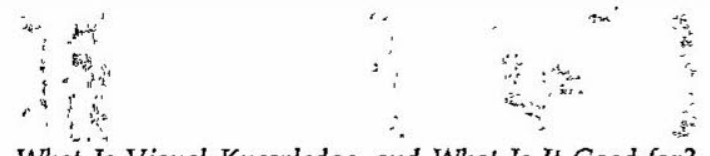

What Is Visual Knowledge, and What Is It Good for?

demonstrative arsenal of maps, diagrams, models, and photographs, lawyers (and the litigation consultants who assist them) are now introducing new kinds of visual and multimedia display. They assemble video previews of the strengths of their cases and show them to opposing counsel in the hope of obtaining favorable settlements [Tarantino 2004; Buckley 1986]. They shoot and edit "day-in-the-life" movies of accident victims for personal injury cases [Joseph 1997: §4.06; Buckley 1986], and compile video montages of murder victims' lives to be used as victim-impact evidence in sentencing proceedings [Hicks v. Arkansas 1997; Salazar v. Texas 2002]. Software programs like Sanction and Trial Director enable them to replay video depositions for judge and jury and simultaneously to display deponents' words on a scrolling transcript [Verdict Systems LLC, Sanction CD-ROM; Indata Corporation; Trial Director CD-ROM]. Advocates digitally enhance photographs and create Photoshop overlays of different forensic images [State v. Swinton 2004]. They use computer animations to illustrate expert witness reconstructions of crimes' and accidents [Joseph 1997: $\S \S 8.01-8.06$ ]. To set the scene for eyewitness testimony, they can use "virtual reality views" - -seamless, 360-degree representations of a scene, composited from digital photographs, with which witnesses can interact, moving in any direction and zooming in or out as desired [Barnett 2004: 693-694; Whelan, 2005]. And to build opening statements and closing arguments around multimedia displays that integrate text, photos, video clips, original graphics; and sound files, lawyers need not rely on the sorts of sophisticated consultants who produced the arguments in the three case examples above. They can do it themselves with PowerPoint [Siemer and Rothschild 2002].

The ongoing transformation of law practice by digital visual and multimedia technologies can be gauged in part by the growing numbers of high-tech courtrooms [Wiggins 2004] and instructional materials for lawyers [Arkfeld 2001; Brenden and Goodhue 2001; Ritter 2004]. But even more importantly; the proliferation of digital and visual tools is profoundly changing the way litigators approach their jobs. First, the ability to put so much of their thinking into visual form leads lawyers to "'brainstorm" and strategize their cases differently. When lawyers visualize a case; different possible relationships between elements can emerge that remain invisible when those same elements are only described verbally. This is because visual spatial arrangements are different from linear linguistic sequences. (Consider this the visual equivalent of the claim that we often discover what we are thinking in the act of writing.) For example, one can talk about information channels in a complex corporate hierarchy, but a box-and-line chart showing who communicated with whom can make instantly intelligible the paths of information and of influence.' Second, the process of assembling and designing the visual presentations to be shown during negotiations, arbitration proceedings, or trials forces lawyers to prepare their cases earlier and more thoroughly than they would otherwise. Advocates must think through their theories of the case up front so that they can plan for, design, and integrate apt visuals at the right spots in their presentations. Third, as scientific and other complex evidence plays an ever-larger role in legal disputes, the move to the visual enables lawyers and their expert witnesses to teach their cases more effectively to judges and juries. By using pictures as well as words, lawyers 


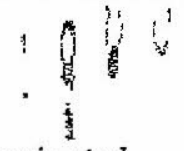

154

R. K. Sherwin et al.

- $\bar{v}$

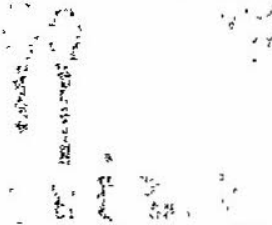

can present their cases in ways that interact more effectively with thejr audiences' diverse styles of learning [Mayer 1989; Mayer and Anderson 1992; Gardner 1993]. This enhanced capacity for visual representation fosters in practitioners a mindset of "lawyer-as-instructor" that may, over time, effectively compete with the more pejorative popular images of the lawyer as "hired gun" and unethical manipulator. (Of course, new digital communication technologies also open up new opportunities for questionable practices, which need to be understood and effectively countered.)

These developments make it incumbent upon us to ask: How and what exactly do juries and judges learn when lawyers use digital and visual media to present evidence and argument? And how does the shift to these media affect the way that lawyers and their audiences reconstruct reality for the purpose of rendering legal judgment?

Today, it is well accepted that our sense of history, like our sense of memory and self-identity, is in large measure the result of composing and telling stories [Sherwin 1996; Amsterdam and Bruner 2000; McAdams 1993; Sarbin 1986; Schafer 1992; Spence 1982]. And just as it is through stories that we construct the meaning of individual and collective experience, so also is it through stories that we are moved to blame or exonerate others [Pennington and Hastie 1993]. To an increasing extent, storytelling in popular culture today is visual. Digital pictures-conveyed through television, movies, videos, CD-ROM, DVD, the Internet, and traditional print media-have come to dominate our entertainments, our politics, our news, and our methods of education, and now they are infusing law practice as well. In fact, pictures have come to be seen by some as more real than technologically unmediated reality [Baudrillard 1900, 1995]. It should not prove surprising, then, that it is the play of pictures invoking other pictures (together with other, more implicit meanings) that we see when lawyers reconstruct reality visually in the courtroom [Meyer 1994; Sherwin 2000].

We offer below four sets of interdisciplinary insights into law's visual and digital meaning-making practices today. This illustrative (but hardly exhaustive) set of tools includes the neurobiology and psychology of vision; cognitive psychology and narrative theory; media studies and reality judgments; and the cultural psychology of digital experience. No one tool or insight explains everything, but each advances the understanding of how advocates and their audiences make meanings. Taken together, these multiple tools and insights from a variety of disciplines establish a network of overlapping and mutually informative methods of analysis and persuasion. This network constitutes the more expansive domain of rhetoric in the digital age. Singly and jointly applied, these rhetorical tools advance the advocate's twin goals of credibly representing reality while persuasively activating decision-makers' memories, emotions, and beliefs in their pursuit of judgment.

\section{Vision Science and Visual Thinking: Why Pictures Matter}

When judges and jurors scrutinize photographs, videos, computer animations, and other graphic materials (such as charts, graphs, and maps) used as demonstrative 
evidence as they strive to reach decisions, they are doing something very different from what they are doing when they listen to testimony or read documents. When they look at pictures, they are reading a different kind of text, which comes with its own methods of decoding, history(ies), and ways of resonating with the rest of our culture. To appreciate how profoundly the visual turn is affecting law, therefore, it is necessary to understand a bit about vision and visuality-what is distinctive about visual perception and visual thinking, and why visual displays can exert an especially strong influence on legal judgment.

Let us begin with the biology and neuropsychology of vision. In spite of the apparently seamless unfolding of the external world through visual perception, people actually construct their ideas about the world through discrete bits of information that they assemble into visual images. With a speed that makes the process seem automatic, people arrive at a conscious sense of continuous perceptions. But that is not the way things are before the brain composes the coherence of perceived reality [Barry 1997; Hoffman 1998; Finkel 1992], To make order out of what might otherwise be a chaos of perceptions, people resort to rapid sortings of data, marking their relative importance so that they may rely on their perceptions to make quick judgments. This capacity to sort perceptions and register their emotional significance rapidly allows people to know when to fight and when to flee [LeDoux 1996], when they need to pay focused attention, and when they can afford to be lost in mental clouds. At least some of the emotional associations that a visual perception acquires attach well before anything like conscious processing occurs, which can lead to stereotyped thinking that goes unnoticed by the rationalizing cortex [Dovidio and Gaertner 1993: 167; Fiske 1998: 357].

Visualization and visual thinking are quick; they are also highly malleable. Basic perceptual judgments are prone to social influence; for example, people are more likely to see two similar objects as the same if told that others have seen them that way [Berns et al. 2005]. Verbal information can remold visual interpretation and memories. In one well-known experiment, participants shown a film of an automobile accident who were asked how fast the cars were going when they "smashed into" one another gave higher estimates of speed than participants who saw the identical film but were asked how fast the cars were going when they "collided with" one another--and, one week later, were more likely to recall having seen broken glass in the film, even though none was actually present [Loftus and Palmer 1974]. Captions guide the interpretation of pictures [Palmer 1999: 597-601; Slattery 1990], and suggestive questioning can induce not merely biased but entirely false visual memories [Lindsay 1999].

Visual thinking is malleable because the images that people think with "are not stored as facsimile pictures of things, or events, or words, or sentences" [Damasio 1994]. There is no one place in the brain in which internal representations of visual percepts or mental imagery "come together" [Finkel 1992]. When people need to think imagistically in response to a given task, they do not simply retrieve intact the appropriate images from their neurological library. Consequently, the beliefs and judgments that people may articulate in response to tasks eliciting visual thinking are not simple read-offs from some internal visual or quasi-visual mental reality [Bennett and Hacker 2003; Wittgenstein 1958: 154, $180]$, any more than their beliefs and judgments about the world in general are 
simply read-offs from external reality. Rather, people (re)construct the mental images they use in their thinking as required by the task and the situation [Churchland 2002: 309, 318]. A more apt metaphor for the mind than a library (or some equivalent "container") might be that of a short-order cook-and not one who dishes up just ham and eggs, but an artful French chef who can nearly instantly combine neural ingredients to create a sumptuous repast to order [Marks 1990: 1, 6]. Perceiving and imaging are not merely processes of identification brought about by looking and listening but active performances in which specific intentions, purposes, and actions need to be fulfilled [Gibson 1979: 253].

In the light of these features of visual perception and thinking, consider some of the ways in which pictures, in contrast to purely verbal communications, can affect legal decision-makers' thinking and judgments (for a more detailed discussion, see [Sherwin 2004: 95, 99-100]):

- Pictures of all kinds-still or moving, diagrammatic or photo-realistic--tend to have a greater impact than nonvisual expressions of the "same" information, because pictures tend to be more vivid. The greater salience of visual information makes it more likely that the viewer will take in the information, remember it, and use it in subsequent judgment tasks [Bell and Loftus 1985; Martin and Williams 1990].

- Visual displays can convey more information than words alone and enable viewers to understand more. For example, spatial arrays, graphs, and diagrams can show relationships between data that would remain obscure if the data remained in tabular notational form [Kosslyn 1994a; Tufte 1983, 1990, 1997]. Similarly, computer-animated reconstructions of events can represent with clarity and precision small but legally significant changes within a given period (such as the relative positions and speeds of vehicles prior to a collision [Dunn et al. 2006; Kassin and Dunn 1997]). These factual details might remain difficult for a decision-maker to imagine, and thus harder to understand, if left to verbal descriptions alone. (Some research has shown that computer animations may not assist legal decision-making where audiences are able to visualize events adequately on the basis of verbal information and nonmoving diagrams alone [Dunn 2001; Bennett, Leibman, and Fetter 1999].)

- Photo-realistic pictures tend to arouse cognitive and emotional responses similar to those aroused by the real thing. For example, an IMAX movie of a rollercoaster ride can induce vertigo in viewers who would remain unruffled by a verbal description [Gunning 1995, Douglas, Lyon, and Ogloff 1997].

- Unlike words, which are obviously constructed by the speaker and thus are understood to be at one remove from the reality they describe, photo-realistic photographs, videos, and film can appear to be caused by the external world (sometimes referred to as indexicality) without the taint of human mediation or authorial interpretation [Mnookin 1998: 16-17]. Consequently, they tend to be accepted as highly credible evidence of the reality they depict, even though they lack the other sensory modalities that the viewer would encounter in real life. (Digital photography and video, however, make this claim highly problematic [Mitchell 1994].) 
- Unlike the linear communication of words, which must be taken in sequentially, much of a still picture's meaning can be grasped all at once. It takes a lot less time and mental effort to see a picture than to read a thousand words [Kosslyn 1994: 10]. This allows decision-makers to take in more information and to develop a better understanding of the case-or at least to feel that they have done so. (What viewers tend to take in rapidly is the organization of the whole and the meaning associated at that level. By getting the Gestalt, viewers may feel that they have understood what they need to know, even though they have not bothered to explore the relations between all the parts of the picture.)

- When people take in photo-realistic pictures, they tend to believe that they have got all there is to get. Consequently, they are disinclined to pursue the matter further. This sense of communicative efficacy is even stronger in timebased media such as film, video, and computer animation, which offer the eye rapid visual sequences. These tend to disable critical thinking, because viewers are too busy attending to the picture immediately before their eyes to reflect on those that have gone before [Barry 1997: 32, 46; Shapiro and McDonald 1992: 108]. As a result, compared to words, visual communications tend to generate less counter-argument and hence more confidence in the judgments they support.

- When pictures are used to communicate propositional claims, at least some of their meaning always remains implicit. Pictures cannot be reduced to explicit verbal propositions [Elkins 1999: 68-74]. In this respect, pictures are well suited to leaving intended meanings unspoken, as would-be persuaders may prefer to do - especially when evidentiary rules or social conventions forbid making a given claim explicitly. (Visual displays can do this much better than words precisely because, not being themselves prepositional, less of what they mean is anchored in what they "say.")

- Finally, pictures, more so than words, convey meaning through associational logic that operates in large part subconsciously, through its emotional appeal [Martin and Williams 1990: 268]. Thus a person may be aware that a picture is strongly linked to an emotional response without knowing or understanding what the connection is [Andersen 1995: 72-85; LeDoux 1996: 71]. And when the emotional underpinnings of judgment remain outside awareness, they are less susceptible to effective critique and counter-argument. (Several psychologists and philosophers have recently emphasized that intuitive emotional responses tend to drive people's moral (and legal) judgments, in part because people's later conscious cognitive processing tends to rationalize decisions already reached rather than to subject them to truly critical scrutiny [Haidt 2001: 814; 2003: 197].)

Now let us consider some illustrations of how skillful advocates take advantage of these attributes of visual communication to help their audiences reconstruct reality: Recall the class action suit against the big tobacco companies to which we alluded earlier. How better to convince jurors that the defendants wanted to keep their customers "hooked" on tobacco than to show how the addiction process actually works? That is precisely what the plaintiffs' evidentiary graphic did. Images of vividly colored ammonia molecules closely interacting with nicotine inside a cigarette made the product engineering process clear. 
Subsequent images of key "nicotine binding sites" in the brain completed the picture. Taken together, these instructive, easy-to-grasp, and highly memorable visual displays quickly and effortlessly conveyed complex technical information that went to the heart of the plaintiffs' claim. The defendants' denials were groundless; their product, in essence a highly efficient nicotine delivery system, was manifestly designed to induce addiction-just as the plaintiffs' trial experts said. Having now seen for themselves the defendants' product in action, what more could the jurors want? Words alone could hardly offset the immediate and enduring impact that this kind of visual persuasion exerts on decisionmakers' thinking and judgment.

Or consider again the criminal case that we introduced earlier on. During the State of Connecticut's closing argument in the trial of Michael Skakel for the murder, 27 years before, of 15-year-old Martha Moxley, jurors heard and saw Skakel's own words appear on the screen before them. As Skakel uttered the word "panic," jurors instantly saw Martha Moxley's lifeless body appear on the screen as it lay at the crime scene. Of course Skakel experienced a "feeling of panic" when Martha's mother asked him the next morning if he had seen Martha the night before. The picture of Martha's battered, lifeless body immediately explains the implicit meaning of his words. The viewer instantly makes the connection: Skakel, upon awakening, must have recalled with horror what he had done the night before. Because the screen-based emotional response and the realitybased response are comparable, the viewer's emotional reaction to the picture of Moxley's body is readily transferred to Skakel. The viewer "knows" what he is reacting to. And the viewer's revulsion at what Skakel had done readily casts an image of guilt in the viewer's mind. This instantaneous understanding elides the passage of time--between the murder and the morning after (in 1975), and between the time when Skakel uttered these words (in 1997) and the time that they were replayed at the trial itself (in 2002). Distance in time and space matters not, for everything takes place in the emotionally salient, temporally flattened now of viewing the screen. And because this understanding is immediate, credible, and seemingly complete, the viewer experiences little reason to question what he or she knows. The defense counsel's purely verbal counter-narrative is unlikely to explain Skakel's panic as convincingly, because it lacks the cognitive and emotional salience of the prosecution's montage [Connecticut $v$. Skakel 2003: 60]. Seeing is believing-or more precisely, belief is more solidly constructed through visual understanding prompted by visual displays.

We have discussed how, as a function of brain physiology and sensory perception, people construct their worlds-both their inner worlds and what they encode about the world outside. We have also noted that visual perception and visual thinking do not occur in a vacuum, separated from other parts of mental life. Traditionally, pictures used in law have been conceived as mere illustrations of words. A more sophisticated approach will better inform advocates' choices about what and how much to show, and what and how much to tell. The conjunctions between pictures and other forms of communication and between visual and verbal thinking, however, also make it important to understand a little more about the various cognitive and narrative frameworks that shape and inform legal advocacy. It is to this topic, therefore, that we turn next.

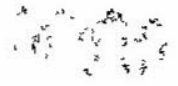




\section{Cognitive Frameworks and Narrative Theory}

People's beliefs and judgments may be more or less firmly tethered to perceived reality, but they always exceed it. To understand a conversation, to make a prediction, or to assign blame, people always do just what they do in response to pictures-they "go beyond the information given," in Jerome Bruner's famous phrase [Bruner 1973]. That is, they interpret and draw inferences from new data in the light of their habits of thinking and feeling, their largely intuitive conceptions of how the world works and how things go.

Cognitive and social psychology help to identify and explain the stuff from which beliefs are made. Psychology outlines the stereotypes people use to classify and judge others; it uncovers the stock scripts that guide expectations about others' behavior and tag deviations as worth accounting for [Bruner 1990; Schank and Abelson 1977]. It describes how everyday cognition conserves scarce mental resources by using mental heuristics or rules of thumb to reach quick answers that are often good enough, but sometimes seriously mistaken IGeigerenzer, Todd, and The ABC Research Group 1999; Gilovich 1991; Nisbett and Ross 1980]. Psychology also shows how people's emotions, while highly variable and seemingly irreducible to any empirical calculus, interact with their perceptions and cognitions to guide judgment and behavior [Damasio 1994; Forgas 1991, 2000]. Other disciplines also strive to articulate the unspoken grounds of comprehension and belief. Studies in the philosophy of language, linguistics, and cultural anthropology, for instance, indicate the implicit understandings that people must share in order to make sense of one another's words [Holland and Quinn 1987; Lakoff 1987].

Of the manifold ways in which humans organize and make sense of their experiences, none may be more important than narrative. "It seems almost as if humankind is unable to get on without stories," write Anthony Amsterdam and Jerome Bruner toward the beginning of their masterly discussion of the subject [Amsterdam and Bruner 2000: 114]. Stories do much more than tell what happened, although that in itself is no small thing. They "give comfort, inspire, provide insight; they forewarn, betray, reveal, legitimize, convince. You can declare your love by telling just the right story at the right time; you can be Lago and create mad suspicion; you can spur Billy Budd to strike Claggart dead" [Amsterdam and Bruner 2000: 115]. A culture's stories-recounted in religious scripture and popular novels, depicted in movies and on television, or enacted in video and computer games-present heroes, villains, and everyone in between confronting conflicts and one other, and thereby teaching us, the audience, how we should feel and what we should do about our own and others' comparable plights.

Lawyers and law are, of course, immersed in stories, from the client's first account of events in the lawyer's office to the versions the lawyers tell each other during settlement negotiations, to the narratives constructed for judge and jury at the trial, to the accounts designed for television news and journalists in other mass media. Each telling is molded as much by perceived audience expectations, conventions of genre and professional practice, and constraints of time and medium as by correspondence to any unnarrated reality. A persuasive legal story 
must be as consistent as possible, not only with the evidence and the judge and jury's understandings of the relevant law, but also with those audiences' senses, developed through lifetimes of exposure to their culture, of "how stories like that go" $^{\prime \prime}$ [Pennington and Hastie 1993].

It is the choice of a particular story (and the mode of telling) as befits the circumstances that tends to capture legal belief and motivate audiences to take the action the advocate desires: acquit or convict, award damages or deny recovery. The story that works best may be as relatively mundane as a personal injury lawyer's allusion to Rocky [United Artists 1976] to depict an accident victim struggling to overcome his undeserved suffering [Feigenson 1995: 61]. Or it may be as transcendent as the story of the founders of the American polity, used by Gerry Spence to cast his white separatist client Randy Weaver as the heroic defender of Jeffersonian liberty against governmental tyranny [Sherwin 2000: 56-58; Spence 1995: 1-48].

Or, drawing once again from one of the case examples offered earlier, consider the narrative strategy that Maxus's lawyers developed for their case against Kidder, Peabody and Martin Siegel [Stachenfeld and Nicholson 1996]. The case, in a nutshell, was that Maxus, a company in the oil business, had hired a prestigious New York investment banker, Martin Siegel, and his firm, Kidder, Peabody, to prepare the takeover of Natomas, another company. But after each meeting Siegel held with Maxus officials, the price of Natomas's shares went up. Maxus claimed that Siegel had passed along inside information to a Kidder executive, Ivan Boesky, who then invested in the target company, driving up its stock prices, with the result that when Maxus eventually acquired Natomas it had to pay hundreds of millions of dollars more than it otherwise would have done. How to invoke the audience's intuitive beliefs so as to convert such a complex commercial dispute involving massive amounts of circumstantial evidence into a simple, credible, compelling storyline that would point the jury to the desired verdict?

The solution was to emplot visually the case as a struggle between us and them, the familiar local guy versus the big bad other-an archetypal conception of how conflict is structured, and who should win, that goes back to the biblical tale of David and Goliath, if not to the Zoroastrian God and Satan (Ahura Mazda and Ahriman). Maxus's closing argument video starts by locating the parties on a map of the United States. Its disproportionate enlargement of Texas, shaped and colored to evoke the state's highly popular flag, must have encouraged the Texan jurors to identify with a home-grown plaintiff and, conversely, drawing on implicit social stereotypes, to distance themselves from the defendants-those "outsiders" from New York. To enhance the effect, at one point jurors saw the state of Texas suddenly snap out of the graphic display as if it were shooting a line (or a lasso?) around New York [Stachenfeld and Nicholson 1996]. In short, the visual argument that Maxus's lawyers used to construct the legal conflict deployed a story frame that anyone familiar with our culture's core moral tales (or the local culture's implicit folk knowledge) could immediately recognize and understand. Martin Siegel, the unscrupulous outsider, is recognizably the "bad guy" in a visually narrated scenario that manifestly prompts the jury's sympathy and animosity along well-established lines. 


\section{Mediated Belief: Popular Visual Culture and Reality Judgments}

In contemporary culture, most people get their facts primarily from popular visual media. Television and the Internet provide more people with news about the world, as well as information about law and politics, than do the more traditional print media [Shin 2005: this has "continued a 20-year trend in the newspaper industry, as people increasingly turn to other media, such as the Internet and 24-hour cable news networks, for information"]. Television's photo-realism, in particular, seems to open an audiovisual "window onto reality" [Potter 1988: 23; Shapiro and MacDonald 1992]. Yet "[t]he medium is the message," as Marshall McLuhan famously proclaimed back in 1964 [McLuhan 1964]. McLuhan's critical insight was that we must disabuse ourselves of the naïve notion that the mass media operate like an empty pipe (or, in the case of television, like a window) through which information passes. In fact, different media exert different kinds of influence on the messages they convey. For example, print culture usually operates in a field of concepts and categories. As Walter Ong has written, "Verbal representation [in the mind] yields associations which indicate that it is specialized for representing hierarchical conceptual structures" [Ong 1982]. Television, by contrast, excels in depicting personal dramas, offering viewers storylines and character types that are familiar and immediately accessible. Television achieves unique emotional power and intimacy by way of the closeup, which brings viewers directly into the emotional field of the characters on the screen. (Consider close-ups on smaller television screens, where viewing distance enhances intimacy.) This is hardly a matter of mere aesthetics. Dramatizing the personal tends to obscure the general. By presenting social problems in terms of personal history and individual character development, television resists complexity, which is notoriously difficult to dramatize in visual form [Bennett 1996: 48-58; Postman 1985]. Conversely, print media coverage of social problems can also tend to oversimplify through dramatization [Stallings 1990: 80].

People's media-spawned expectations are guided by the visual codes not only of television but also of film, especially major Hollywood movies. The visual codes that come from popular culture become a part of people's visual commonsense-which is to say, they are unconsciously assimilated. People understand cross-cutting and parallel editing. They do not need anyone to explain these storytelling devices. The camera is inside the audience's heads, and they are prepared to reconstruct reality in accordance with the perceptual and cognitive codes they have internalized.

People also generally suppose that they know reality when they see it, that they can, by and large, distinguish humbug from the genuine article. They kick the tires and don't take any wooden nickels. And when people "suspend disbelief" to indulge in a novel, a film, or a television drama, they like to think they do so "willingly." Yet, considerable psychological research shows that it is not so easy to know what to believe, or when. Credulity, not skepticism, is the default mode. When people readily understand something they are inclined to believe it [Gilbert 1991: 107]. Disbelief must be effortfully engaged; it is what people do when they assess critically what they have already provisionally accepted as true [Prentice, Gerrig, and Bailis 1997: 416]. 
The visual mass media provide people not only with most of their facts but also with most of their fictions. Indeed, people's world knowledge draws upon a mixture of fictional and nonfictional sources [Prentice and Gerrig 1999: 529], and they are not always able to differentiate real from fictional sources of remembered information [Johnson and Raye 1981: 67]. The striking irony is that facts can seem more "factual" the more like fiction they become. This happens because people generally are less motivated to process fictional information systematically than factual information [Prentice and Gerrig 1999: 544]. When an audience unwittingly responds to a factual presentation as if it were fiction, the default mode-credulity-kicks in. Critical analysis, not disbelief, gets suspended. Effective critique requires not only knowledge of the requisite tools of critical analysis but also the energy and inclination to undertake it. By contrast, stored-away fictions effortlessly come to mind when a familiar narrative genre, character, or situation type stimulates people's recollection. That is part of what is going on when a trial lawyer compares a witness or a defendant to a well-known character from The Godfather, Natural Born Killers, or The Sopranos [Sherwin 2000: 16-17]. If the comparison sticks, the jury tends to fill in the rest of the story, including character traits unmentioned at the trial, even if they are fictional.

The codes and content of modern visual storytelling, from television dramas and news shows to advertisements and feature films, have infiltrated the courtroom so that fact and fiction, information and entertainment, work hand in hand in the production of legal truth. For example, consider again in this regard the closing argument video that was used in a negligence lawsuit against Price Waterhouse. The video seamlessly shifted from documentary images of the real Titanic to clips from a British feature film entitled A Night to Remember [1958], in which we see indifferent officers and a preoccupied captain appear to recklessly disregard a telegram warning about the presence of icebergs in the ship's vicinity. (The trial judge's admission of this video was reversed on appeal [Standard Chartered PLC v. Price Waterhouse 1989/1996; Sherwin 2000: nn. 39-40; Sherman 1993: A1].) The upshot is clear: Being the largest in the world is no safeguard against negligence.

Or consider again, this time from a popular cultural perspective, the Maxus insider trading case against Kidder, Peabody. In the visual graphic used by the plaintiffs in their closing argument, the jurors saw the defendant, Martin Siegel, perched in a three-by-three grid reminiscent of the tic-tac-toe board featured in the once-popular television game show, "The Hollywood Squares." When the nine Siegels are seen and heard simultaneously "taking the Fifth," the effect is highly comical. The viewer laughs at the incongruous sight of a once-esteemed Wall Street investment banker cast in a TV game show that typically featured celebrity has-beens desperate to somehow revitalize their careers (or, at least make a buck). That this response, and the normative associations that it carries, is being triggered by an iconic game show, however, remains implicit, unarticulated, and hence unavailable to critical reflection. The humor on display is disarming, but there is a more serious intent at work here. The visualization of the incanting Siegel diminishes him by implicitly portraying him as just another celebrity has-been-but it also demonizes him as well. The humorous gloss of 
Siegel ensconced in all nine squares distracts the decision-maker from a legally impermissible inference that may also be taking place: namely, the association of Siegel with other so-called "Fifth Amendment criminals" who hide the truth of their misdeeds behind a wall of silence. Of course, to say that this apparently innocuous visual display penalizes the defendant for exercising his constitutional privilege against compelled self-incrimination not only seems counter-intuitive from the standpoint of ordinary commonsense (after all, the video clips accurately depict what Siegel said at his deposition), but also spoils the simple fun of the display.' In sum, the viewer gets the message because the visual code of a popular television game show icon is instantly recognizable, and the critical bite of an impermissible (albeit unconscious) inference remains hidden. To preserve the joke, the viewer is disinclined to analyze it critically.

To acknowledge that Maxus's "Hollywood Squares" display constructs its visual argument in the form of a shrewd joke is to reassert one of the points we have been making: This seemingly simple visual display is decidedly not a mere illustration of ideas that could just as well be expressed verbally. To analyze its rhetoric, we have drawn on the psychology of visual perception, the social psychology of mental frameworks, narrative theory, and the conflation of fact and fiction in contemporary culture and the human mind. In the next section we add one more set of conceptual and rhetorical tools, an essential part of the multidisciplinary network of insights that lawyers need in order to understand law in the digital age $\cdots$,

\section{Digital Cultủre/Digital Mind}

Good tools serve the purposes for which they were initially designed, but they also suggest additional, often unexpected, uses and lead to new forms of understanding that inspire the building of yet other tools. Consider, for example, the computer mouse invented by Douglas Engelbart and his team at the Stanford Research Institute in California: In 1968, they demonstrated a networked computer system that had the rudiments of two-dimensional display editing, flexible view control, on-screen:video teleconferencing-and a mouse [http://sloan. stanford.edu/mousesite/, last visited July.6, 2005]. Anyone using a computer now knows how to use a mouse to navigate and enter commands. Forty years ago, however, these functions were not yet the highly developed technologies with which we are familiar today. But they projected a vision of human-computer interaction that inspired innumerable subsequent innovations, from the graphical user interface (which permits people to use multiple applications at the same time) to full-fledged hypermedia. Just as those technical ideas were seeded in a professional community and eventually grew into unexpected, even astonishing, fruit, exposure to and use of digital technologies is already generating new behaviors and new patterns of thought in the law.

Advanced digital imaging capacities are now widely dispersed. (Recent Info Trends/CAP Ventures forecasts show that U.S. consumer digital camera penetration would reach 55 percent and shipments of around 25 million in 2005, growing to 81 percent and about 21 million units shipped in 2010.) In the 
" was

past, a lawyer might order a graphic from a designer and have no real idea of how it was made. Now that lawyer probably owns a digital camera and can upload and make simple edits (like cropping or adjusting the orientation or the contrast between light and dark). The Excel program makes it easy to graph data; word-processing programs make it easy to design pages and incorporate pictures and tables into texts. Other readily available software allows people to lay out entire books and create two-dimensional animations. In short, what used to be the specialized knowledge of graphic designers using tools affordable only by those with professional commitments is now available to all computer users at consumer prices for use at home or at work, as freeware, or as software running on computers in schools, libraries, and copy shops.

The same is true with respect to moving images. Almost anyone can make them-even still cameras and cell phones are now capable of making short video clips-and anyone can modify anything they or anyone else has made. Good hands and expensive tools are no longer needed. Pointing and clicking have become physical habits; seeing pictures as potential material and not just as someone's property is one of the new mental habits. Repurposing others' visual work is not something new. Artists have been quoting each other and learning by copying from the beginning. Now, however, it can be done with "original" digital data; anyone, even lawyers, can do it; and their art can be published on the Internet and disseminated globally at virtually no cost.

The ubiquity of surveillance and amateur video cameras in conjunction with a broad range of readily available and easy-to-use image-editing tools has given rise to many more kinds of demonstrative evidence. This was dramatically illustrated in the cases arising out of the New York Police Department's mass arrests of protesters outside the 2004 Republican National Convention, in which dozens of amateur videos were introduced to refute (and, in a few cases, to confirm) police claims that the protesters had behaved illegally [Dwyer 2005: A1; Medina and Holl 2005: B3; on the political dislocations created by ubiquitous photo-imaging in public spaces, see Azoulay 2001: 287]. But the widespread experience of modifying and manipulating pictures has even deeper cultural and cognitive significance. The typical lawyer may not be adept at using advanced professional editing software like Adobe Photoshop, but in all likelihood he or she will have heard of "photoshopping" as a verb referring to altering a picture. Today, in an era when digital pictures are infinitely malleable, when, in the words of William Mitchell, "the referent has come unstuck" [Mitchell 1994b: 31], people may have to give up their naïve sense of the photo-realistic picture as metonymic truth [Kibbey 2005: 12-18]. In exchange, they will gain an understanding of the picture as a construct, a text to be actively construed rather than a window onto the world that merely needs to be looked through [Ritchin 1999: 124].

So far we have addressed changes in the pictorial texts themselves. The Internet has also profoundly changed people's relationship to the screen on which those texts are seen. On cinema screens, people became accustomed to seeing their dreams writ large while sitting with others in a dark, cavernous room. Television, by contrast, with its comparatively small screen, brought news of the world and entertainment into the intimate sphere of the household, becoming a character in family life, a familiar. Personal computer screens differ from both. 
Unlike televisions, where groups can gather around for a common experience and comment, personal computers are more often in places where people use them alone, and their interactions with others are through the machine rather than across the table or along the couch. However, people also respond to what they see on screens in many ways that are similar to how they respond to social encounters in real life [Reeves and Nass 1996]. And at the same time, people expect to do things; to be engaged, with what they see on the screen. (Indeed, for some the engagement with the machine and the virtual worlds it yields can become an obsession [Turkle 1995].)

Participating in mediated digital environments is, of course, what computer gaming is all about: Multiplayer online games such as "Second Life" provide complete social environments for their participants 'Linden Research, Inc. 2003]. Successful play, moreover, involves not just interacting with other players within a framework of rules and protocols, but remaking one's digital world by reprogramming it. Increasingly, prospective jurors (and not only younger ones) may come to court with the expectation not only that witnesses and lawyers will navigate multimedia presentations through pointing and clicking (as in the Skakel case), but also that they will themselves be allowed to participate in the recreation of legal reality.

Lawyers are already beginning to cater to people's expectation that, in the digital era, information is something that they can and should be able to seek out and interact with; rather than something that they passively receive. Consider the virtual-reality view, a seamless, 360-degree representation of a scene composited from digital or digitized photographs. Users navigate the scene, moving in any direction and zooming in or out as desired. American lawyers have used virtual-reality views in a handful of cases as illustrative aids to clarify eyewitness testimony. In the United Kingdom, an even more complex "virtual-reality system" has been used by witnesses before the Bloody Sunday Tribunal, established in 1998 to reexamine the facts of the 1972 killing of 13 Northern Irish citizens by British soldiers in the streets of Derry. Interacting with computer-generatedviews of various locations in Derry, witnesses have been able to revisit scenes from any angle and draw arrows on the screen to describe the events and movements they recalled. In some instances the virtual-reality system has enabled the Tribunal to confirm that it was physically possible for witnesses to have seen what they remembered seeing, given the layout of the city and the witnesses' locations at the time [The Bloody Sunday Inquiry, http://www.bloody-sundayinquiry.org.uk].

Or consider the Soham double homicide case in England. The defendant stood accused of the murder of two :young girls [http://news.bbc.co.uk/1/hi/ england/3243025.stm]. The government's case was circumstantial. At its heart were the sweater fibers from the clothing worn by the two young female victims at the time of their disappearance and death. The jurors not only got to see those fibers in open court, the judge also gave them a DVD to play during their deliberations. (The prosecution team considered 6,820 statements, 7,341 exhibits, and hundreds of hours of video footage and media coverage. The police enquiry generated approximately 24,000 documents $\cdots$ [http://www.cps.gov.uk/news/ pressreleases/archive/139_03.htmll.) As a result, in the course of reconstructing 
for themselves the story of the case, the jurors were able to move freely among the digital evidence contained on the disc, which included images of the fibers, the sweaters they came from, the crime scene, the girls' route home, videotaped witness testimony, and other evidentiary material. This kind of free-ranging interactivity with digital evidence may foreshadow how legal meanings will be made in the digital era. Lawyers may have to rethink their rhetorical strategies, making space for their audiences to enter, and allowing them to feel that they are helping to construct the case along with counsel [Bermant 1999: 524; Carrington 1998: 1516].

\section{CONCLUSION: THE CHALLENGES OF VISUAL KNOWLEDGE}

Re-envisioning legal and ethnographic theory in the digital age turns our attention both to new sources of meaning and to new meaning-making practices. Nearly a quarter of a century ago, Robert Cover wrote:

We inhabit a nomos - a normative universe. We constantly create and maintain a world of right and wrong, of lawful and unlawful.... No set of legal institutions or prescriptions exists apart from the narratives that locate it and give it meaning. For every constitution there is an epic, for each Decalogue a scripture. Once understood in the context of the narratives that give it meaning, law becomes not merely a system of rules to be observed, but a world in which we live. [Cover 1983: 4]

Law is a world in which we live. But to live in a nomos, we need a corpus of inherited texts and a common set of interpretive practices. Out of these materials and practices we sustain and revise institutions, paradigms for behavior, and patterns of discourse. A stable society agrees upon (at least to a significant extent), although not without controversy and debate, a shared repertoire of moves, "a lexicon of normative action," that it recombines and supplements to meet the needs of changing times [Rawls 1993: 133-172; Ackerman 1980: 358-359; Durkheim 1974: 92; Turner 1974: 50-56; Cover 1983: 9; Jaeger 1939: xiv, xxvi].

The specific challenge that ethnographers and jurists face today is to translate, under new cultural and technological conditions, the complexity of multidisciplinary discourse into forms of rhetoric and practice that are productive and deemed legitimate within the specific constraints and demands of their respective professional identities. To accomplish this task we need a rich enough toolkit for thick cultural description and analysis. That is what a rhetorical-constructivist approach is intended to offer. From this view, visual ethnography and visual legal studies involve more than words and sentences, as they also take visual images, including computer-generated images and simulations, as part of their subject matter. In addition, they also address the matter of visual literacy, how the various interpretive tools we use make sense of images in a given context. In this respect, professionals in both law and ethnography must be able not only to grasp the components of visual literacy in local settings but also to gain mastery over the various ways in which the visual medium constructs meaning in its own right. Legal and ethnographic films may at times be connotative in nature in order to convey the affective and synaesthetic qualities of meaning-making. At

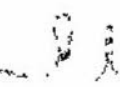


other times, however (for example, in the classroom or when deconstructing a "flawed" visual document for the benefit of judge or jury inside a courtroom), legal and ethnographic visual discourse may need to take a denotative turn, shifting voice and genre to suit the need of the moment.

The kind of integration of theory and practice we are recommending has multiple roots in the scholarly legal culture, including legal realism, legal pragmatism, critical legal studies, law and literature, law and norms theory, and the more recent genre of cultural legal studies [Coombe 1998; Kahn 1999; Post 1991; Sarat and Kearns 1998; Binder and Weisberg 1997: 1149; Silbey 1992: 39; Symposium 2001: 3]. A common denominator among these diverse approaches to legal studies is multidisciplinarity. Notably, cultural studies, out of which the cultural legal studies movement emerged, have been providing scholars outside the legal academy with interdisciplinary tools since the late 1970s [Hall 1978; Williams 1980]. Cultural studies focus on the production, circulation, and assimilation of symbolic forms. They are largely concerned with how institutions and local practices generate social meanings [Turner 1993: 411].

Cultural legal studies adopt this focus, seeking to go beyond appellate case law, statutory interpretation, and social policy, the dominant topics of law teaching and academic writing, in order to encompass legal meaning-making practices more broadly throughout society [Sherwin 2004]. Simply stated, the central question that cultural legal studies asks is: What are the popular cultural codes, the familiar schemas and scripts, the common vocabularies of motive and intentionality, and the hierarchy of beliefs and values that are in play within a given site of legal conflict? 'As Barbara Yngvesson has written, "[t]he spirit of law isn't just invented at the top, but is transformed, challenged and reinvented in local practices that produce a plural legal culture in contemporary America" [Yngvesson 1989: 1689]. Whether it is starting rumor campaigns to contest corporate control over cultural symbols" [Coombe 1998], getting a court clerk to admit a story of abuse as a legal claim [Yngvesson 1989], or resisting mediators who construct images of problems in therapeutic as opposed to legal terms [Silbey and Merry 1986: 7], these practices at the local level constitute the "microphysics of power" (to use a ' Foucauldian phrase). Cultural legal studies' multidisciplinary microanalyses of concrete legal practices counterbalance, without eradicating the need for, critical theory. By proffering localized strategies of rhetorical affirmation and belief, they complement the prevailing ethos of suspicion that marked (and ultimately undercut) critical legal studies.

The constructivist approach we have presented in this essay extends prior theory in several directions. First, it invites an even more broadly interdisciplinary (and thus arguably more fully pragmatic) method. The cluster of conceptual tools we have discussed and applied above is merely illustrative of a much more comprehensive lawyer's toolkit, a yet-to-be-written rhetorical handbook for the digital age. Second, it expands the search for the constitutive elements of legal consciousness-which' is to say, the cultural materials out of which legal meanings are shaped, disseminated, and absorbed-to explicitly encompass the quotidian world of graphic design, film, television, and the Internet, among other digital and multimedia resources. Third, and perhaps most importantly, it urges the study-from multiple perspectives and with an eye toward their theoretical, pragmatic, and 
pedagogical ramifications of the manifestations of legal consciousness in the visual and digital media that have come to pervade the practice of law.

With the ascendancy of electronic monitors inside the courtroom and out, students, teachers, and practitioners of law must be able to account for the everyday associations that decision-makers bring to the screen. They must also be able to accommodate the familiar cognitive programs and information schemas that viewers absorb from computers at home and in the office. By the same token, they will also need to come to grips with changing expectations among decision-makers who have grown accustomed to surfing screen data for themselves. As computer users internalize the thinking tools provided by software in conjunction with Internet-bred habits of data searching via free association, adjustments may be needed in legal communication and advocacy. In short, legal and, we venture to suggest, anthropological training must now adapt to the contingencies of technology and the emerging vernacular of digital culture and the digital mind [Lessig 1999].

In our view, retooling the legal and ethnographic mind so that it may be better adapted to function effectively in a legal (and popular) culture transformed by new communication technologies constitutes the most pressing challenge before the academy today. The task is to make sense of the nature and practice of our respective fields in a nonessentialist, screen-dominated, and pervasively visual environment. We believe that jurists and ethnographers face similar challenges. All of us must ask: What kinds of knowledge and meaning are created, and with what outcomes, when they are visually and digitally constructed in particular ways? And what are the implications for the search for truth and the perennial clashes between knowledge and eloquence, rational dialectics and rhetoric, ethical obligation and aesthetic pleasure (aesthesis), and belief and disenchantment in the current digital age?

Meeting the challenges presented by the production, dissemination, and interpretation of visual knowledge requires a new intellectual framework not only for law and ethnography but also for the human sciences more generally. This new framework incorporates both the familiar word-and-text mode of thinking as well as the pervasively visual, hyper-mediated, and digital mode that increasingly characterizes contemporary cultural practices, including the practice of ethnography and law.

\title{
NOTE
}

1. An earlier version of this essay appeared as "Law in the Digital Age: How Visual Communication Technologies are Transforming the Practice, Theory, and Teaching of Law" in the Boston University Journal of Science and Technology Law, 12(2) [2006].

\section{REFERENCES}

\author{
Ackerman, Bruce \\ 1980 Social Justice in the Liberal State. New Haven: Yale University Press. \\ Amsterdam, Anthony, and Jerome Bruner \\ 2000 Minding the Law. Cambridge, Mass.: Harvard University Press.
}


Andersen, Robin

1995 Consumer Culture and TV Programming. Boulder, Colo.: Westview Press.

Arkfeld, Michael

2001 The Digital Practice of Law: A Practical Reference Applying Technology Concepts to the Practice of Law. Phoenix: Law Partner Publishing.

Ashworth, Susan

2005 TV Facts Then and Now. Digital World, February. http://www.pcworld.com/news/ article/0,aid,118945,00.asp.

Austin, J. L.

1962 How to Do Things with Words. Cambridge, Mass.: Harvard University Press.

Aylwin, Susan

1990 Imagery and Affect: Big Questions, Little Answers. In Imagery: Current Developments. P. J. Hampson, D. F. Marks, and J. T. E. Richardson, eds. Pp. 247-267. London and New York: Routledge.

Azoulay, Ariella

2001 Death's Showcase: The Power of Image in Contemporary Democracy. Cambridge, Mass.: MIT Press.

Banaji, Mahzarin R., and Anthony G. Greenwald

1995 Implicit Association Test. IAT Corp. https://implicit.harvard.edu/implicit/.

Banks, Marcus, and Howard Morphy

1997 Rethinking Visual Anthropology. New Haven: Yale University Press.

Barnett, Jeremy

2004 The Unted Kingdom. William and Mary Bill of Rights Journal, 12: 687-698.

Barry, Anne Marie Seward

1997 Visual Intelligence: Perception, Image, and Manipulation in Visual Communication. Albany: State University of New York Press.

Baudrillard, Jean

1990 Fatal Strategies. New York: Semiotext(e); London: Pluto.

1995 The Gulf War Did not Take Place. Bloomington: Indiana University Press.

BBC News, ‘.

2003 Prosecution Key Points: Day One. BBC News, Nov. 6, 1-2. http://news.bbc.co.uk/1/hi/ england $/ 3243025$.

Bell, Brad E., and Elizabeth F. Loftus

1985 Vivid Persuasion in the Courtroom. Journal of Personality Assessment, 49: 659-664.

Bennett, M. R., and P. M. S. Hacker

2003 Phlosophical Foundations of Neuroscience. Malden, Mass: Blackwell Publishing.

Bennett, R. B. Jr., J. H. Leibman, and R. E. Fetter

1999 Seeing Is Believing, or Is It? An Empirical Study of Computer Simulations as Evidence. Wake Forest Law Review, 34: 257-294.

Bennett, W. Lance

1996 News: The Politics of Illusion. 3rd ed. New York: Longman.

Bermant, Gordon

1999 Courting the Virtual: Federal Courts in an Age of Complete Interconnectedness. Ohio Northern University Law Review, 25: 527-562.

Berns, G. S., J. Chappelow, C. F. Zink, G. Pagnoni, M. E. Martin-Skurski, and J. Richards

2005 Neurobiological Correlates of Social Conformity and Independence during Mental Rotation. Biological Psychiatry, 58: 245-253.

Bernstein, Richard J.

1985 Beyond Objectivism and Relativism: Science, Hermeneutics, and Praxis. Philadelphia: University of Pennsylvania Press.

Binder, Guyora, and Robert Weisberg

1997 The Critical Use of History: Cultural Criticism of Law. Stanford Law Review, 49: 1149-1221. Black, Max

1962 Models and Metaphors: Studies in Language and Philosophy. Ithaca, N.Y.: Cornell University Press. 
Boyle, James

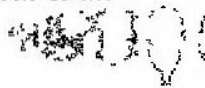

1996 Shamans, Software and Spleens: Law and the Construction of the Information Society. Cambridge, Mass.: Harvard University Press.

Brenden, Ann, and John Goodhue

2001 Persuasive Computer Presentations: The Essential Guide for Lawyers. Chicago: Law Practice

Bruner, Jerome Management Section, American Bar Association.

1973 Beyond the Information Given: Studies in the Psychology of Knowing. New York: Norton.

1990 Acts of Meaning. Cambridge, Mass.: Harvard University Press.

Burns, Robert P.

1999 A Theory of the Trial. Princeton, N.J.: Princeton University Press.

Carney, Brian, and Neal Feigenson

2004 Visual Persuasion in the Michael Skakel Trial: Enhancing Advocacy through Interactive Media Presentations. Criminal Justice Magazine, 19(1): 22-35.

Carrington, Paul D.

1998 Virtual Civil Litigation: A Visit to John Bunyan's Celestial City. Columbin Law Review, 98: 1516-1537.

Cassirer, Ernst

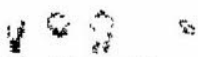

1946 Language and Myth. New York: Dover Publications.

Clifford, James

1988 The Predicament of Culture: Twentieth Century Ethnography, Literature, and Art. Cambridge, Mass.: Harvard University Press.

Churchland, Patricia Smith

2002 Brain-Wise: Studies in Neurophilosophy. Cambridge, Mass.: MIT Press.

Coombe, Rosemary J.

1998 The Cultural Life of Intellectual Properties: Authorship, Appropriation and the Law. Durham, N.C.: Duke University Press.

Courtroom Project 21

[n. d.] http://www.wm.edu/law/courtroom 21/(accessed August 5, 2005).

Cover, Robert M.

1983 Nomos and Narrative. Harvard Law Review, 97: 4-68.

Crown Prosecution Service

2003 Soham Murder Case: Huntley and Carr Guilty. Archived Press Releases, Dec. 17. http:// www.cps.gov.uk/news/pressreleases/archive/2003/139_03.html.

Curtis, Dennis, and Judith Resnik

1987 Images of Justice. Yale Law Journal, 96: 1727-1772.

Damasio, Antonio R.

1994 Descartes' Error: Emotion, Reason, and the Human Brain. New York: Putnam.

Deger, Jennifer

2007 Viewing the Invisible: Yolngu Video as Revelatory Ritual. Visual Anthropology, (this issue).

Deleuze, Gilles

1993 The Fold: Leibniz and the Baroque. Minneapolis: University of Minnesota Press.

Douglas, K. S., D. R. Lyon, and J. R. P. Ogloff

1997 The Impact of Graphic Photographic Evidence on Mock Jurors' Decisions in a Murder Trial:

Probative or Prejudicial? Law and Human Behavior, 21: 485-501.

Dovidio, John, and Samuel Gaertner

1993 Stereotypes and Evaluative Intergroup Bias. In Affect, Cognition, and Stereotyping: Interactive Processes in Group Perception. Diane Mackie and David Hamilton, eds. Pp. 167-193. San Diego: Academic Press.

Dwyer, Jim

2005 Videos Challenge Hundreds of Convention Arrests. New York Times, April 12, A1.

Dunn, Meghan A.

2006 The Jury Persuaded (and Not): Computer Animation in the Courtroom. Law and Policy, 28: 228-248. 
Durkheim, Emile

1974 Sociology and Philosophy. New York: The Free Press. i.

Eichenwald, Kurt

1992 Kidder Will Pay Maxus $\$ 165$ Million to Settle Insider Suit. New York Times, Oct. 12, D1.

Elkins, James

1999 The Domain of Images. Ithaca, N.Y.: Cornell University Press.

2003 Visual Studies: A Skeptical Introduction. New York: Routledge.

Estrich, Susan

1989 The Politics of Race. Washington Post Magazine, April 23, W20.

Feigenson, Neal R.

1995 The Rhetoric of Torts: How Advocates Help Jurors Think about Causation, Reasonableness, and Responsibility. Hastings Law Journal, 47: 61-165.

Feldman, Allen

1996 From Desert Storm to Rodney King via ex-Yugoslavia: On Cultural Anaesthesia. In The Senses Still: Perception and Memory as Material Culture in Modernity. C. Nadia Seremetakis,

Finkel, Leif $\mathrm{H}$. ed. Pp. 87-107. Chicago: University of Chicago Press.

1992 The Construction of Perception. In Incorporations. Jonathan Crary and Sanford Kwinter, eds. Pp. 392-405. New York: Zone.

Fiske, Susan T.

1998 Stereotyping, Prejudice, and Discrimination. In Handbook of Social Psychology. 4th ed. D. T. Gilbert, S. T. Fiske, and G. Lindzey, eds. Pp. 357-413. Boston: McGraw-Hill; New York: Oxford Uniwersity Press.

Flusser, Vilém

1983 Towards a Philosophy of Photography. London: Reaktion.

1999 The Shape of Things: A Philosophy of Design. London: Reaktion.

Forgas, Joseph P.

1991 Emotion and Social Judgments. Oxford and New York: Pergamon Press.

2000 Feeling and Thinking: The Role of Affect in Social Cognition. Cambridge and New York: Cambridge University Press; Paris: editions de la Maison des Sciences de l'Homme.

Galison, Peter

1997 Image and Logic: A Material Culture of Microphysics. Chicago: University of Chicago Press.

Gardner, Howard 1993 Multiple Intelligences: The Theory in Practice. New York: Basic Books.

Gately, Gary

2005 Police Counter Dealers' DVD with One of Their Own. New York Times, May 11, A12.

Geertz, Clifford

1983 Local Knowledge: Further Essays in Interpretive Anthropology. New York: Basic Books.

Geigerenzer, Gerd, Peter M. Todd, and The ABC Research Group ".

1999 Simple Heuristics that Make Us Smart. New York: Oxford University Press.

Gerrig, Richard

1993 Experiencing Narrative Worlds: On the Psychological Activities of Reading. New Haven: Yale University Press.

Gibson, J. J.

1979 The Ecological Approach to Visual Perception. Boston: Houghton Mifflin.

Gilbert, Daniel

1991 How Mental Systems Believe. American Psychologist, 46: 107-119.

Gilovich, Thomas

1991 How We Know What Isn't So: The Fallibility of Human Reason in Everyday Life. New York: Free Press.

Goodman, Nelson

1976 Languages of Art. Indianapolis: Hackett Publishing Company.

Goodrich, Peter

1987 Legal Discourse: Studies in Linguistics, Rhetoric, and Legal Analysis. London: Macmillan. 
Goodwin, Charles 管

2001 Practices of Seeing Visual Analysis: An Ethnomethodological Approach. In Handbook of Visual Analysis. T. van Leeuwen and C. Jewwitt, eds. Pp. 174-178. London and Thousand Oaks, Calif: Sage.

Gregory, Richard L.

1997 Eye and Brain: The Psychology of Seeing. 5th ed. Princeton, N.J.: Princeton University Press. Gunning, Tom

1995 An Aesthetic of Astonishment: Early Film and the (In)Credulous Spectator. In Viewing Positions: Ways of Seeing Fllm. Linda Williams, ed. Pp. 114-133. New Brunswick, N.J.: Rutgers University Press.

Hacking, lan

1983 Representing and Intervening: Introductory Topics in the Philosophy of Natural Science. Cambridge and New York: Cambridge University Press.

Haidt, Jonathan

2001 The Emotional Dog and Its Rational Tail: A Social Institutionist Approach to Moral Judgment. Psychological Review, 108: 814-834.

2003 The Emotional Dog Does Learn New Tricks: A Reply to Pizarro and Bloom. Psychological Review, 110: 197-198.

Hall, Stuart

1978 Policing the Crisis: Mugging, the State, and Law and Order. New York: Holmes \& Meier.

Hanson, F. Allen

2002 From Key Numbers to Keywords: How Automation Has Transformed the Law. Law Library Journal, 94: 563-600.

Herrnstein Smith, Barbara

1988 Contingencies of Value: Alternative Perspectives for Critical Theory. Cambridge, Mass.: Harvard University Press.

Hirsch, Kenneth J., and Wayne Miller

2004 Law School Education in the 21st Century: Adding Information Technology Instruction to the Curriculum. William and Mary Bill of Rights Journal, 12: 873-885.

Hoffman, Donald $D$.

1998 Visual Intelligence: How We Create What We Sce. New York: W. W. Norton.

Holland, Dorothy, and Naomi Quinn

1987 Cultural Models in Language and Thought. Cambridge and New York: Cambridge University Press.

Hughes-Freeland, Felicia

2004 Working Images. In Working Images: Visual Research and Representation in Ethnography. Sarah Pink, László Kürti, and A. Alfonso, eds. Pp. 204-218. London and New York: Routledge.

Jaeger, Werner

1939 Paideia: The Ideals of Greek Culture. New York: Oxford University Press.

Johnson, Marcia K., and Carol L. Raye

1981 Reality Monitoring. Psychological Review, 88: 67-85.

Johnson, Steven

2005 Everything Bad is Good for You: How Today's Pop Culture is Actually Making Us Smarter. New York: Riverhead Books.

Joseph, Gregory P.

1997 Modern Visual Evidence. New York: Law Journal Press.

Kahn, Paul W.

1999 The Cultural Study of Law: Reconstructing Legal Scholarship. Chicago: University of Chicago Press.

Kahney, Leander

2004 Home-brew IPod Ad Opens Eyes. Wired News, Dec. 13. http://www.wired.com/news/ mac/0,2125,66001,00.html.

Kassin, Saul M., and Meghan A. Dunn

1997 Computer-Animated Displays and the Jury: Facilitative and Prejudicial Effects. Law and Human Behavior, 21: 269-281.

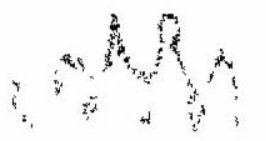


Kemple, Thomas $\mathrm{M}$.

1995 Litigating Illiteracy: The Media, The Law, and The People of the State of New York v. Adelbert Ward. Canadian Journal of Law and Society, 10 (Fall): 73-97."

Kibbey, Ann

2005 Theory of the Image: Capitalism, Contemporary Film, and Women. Bloomington: Indiana University Press.

Kosslyn, Stephen M.

1994a Elements of Graphic Design. New York: W.H. Freeman.

1994b Image and Brain: The Resolution of the Imaginary Debate. Cambridge, Mass.: MIT Press.

Lakoff, George ' ' '

1987 Women, Fire, and Dangerous Things: What Categories Reveal about the Mind. Chicago: University of Chicago Press." $"$ " th "

Latour, Bruno - $\quad *, \cdots, \quad$,

1987 Sctence in Action: How to Follow Scientists and Engineers through Society. Cambridge, Mass.:

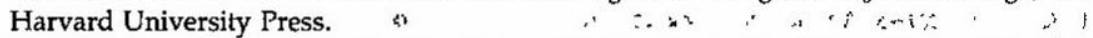

1999 Pandora's Hope: Essays on the Reality of Science Studies. Cambridge, Mass.: Harvard University Press. $\quad \because, x \rightarrow+\infty$

Linden Research, Inc.

2003 Second Life. CD-ROM.

Latour, Bruno, and Steve Woolgar

1987 Laboratory Life: The Social Construction of Scientific Facts. 2nd ed. Princeton, N.J.: Princeton University Press. $*$ a

Lederer, Fredric I: $\quad: \quad, \cdot s$

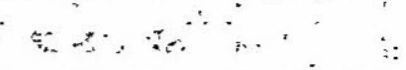

1998 Courtroom Technology and Its Educational Implications. Education and Practice, 8: 3.

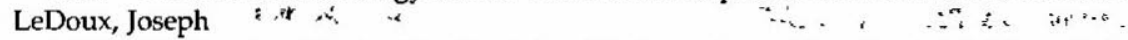

1996 The Emotional Brain: The Mysterious Underpinnings of Emotional Life. New York: Simon \& Schuster. $\%$

Lessig, Lawrence ti th.

1999 Code: And Other Laws of Cyberspace. New York: Basic Books. ' . .

Lifton, Robert Jay

1999 The Protean Self: Human Resilience in an Age of Fragmentation. Chicago: University of Chicago

Press. $\quad \therefore$, ; 5,0

Linden Research, Inc. 's,

2003 Second Life. CD-ROM.

Lindsay, D. Stephen

1999 Recovered-Memory Experiences. In Recovered Memories of Child Sexual Abuse: Psychological, Social, and Legal Perspectives on a Contemporary Mental Health Controversy. Sheila Taub, ed.

Liptak, Adam Pp. 142-164. Springfield, Ill.: C.C. Thomas Publishers. ' :-'

2004 Trial for a Mother Who Drowned 5 Children. New York Times, (Jan. 7): A16.

Llewellyn, Karl $i \rightarrow ?,:$

1960 The Common Law Tradition: Deciding Appeals. Boston and Toronto: Little, Brown \& Co.

Loftus, Elizabeth F., and Johr C. Palmer " $*$ *

1974 Reconstruction of Automobile Destruction: An Example of the Interaction between Language and Memory. Journal of Verbal Learning and Verbal Behavior, 13: 585-589.

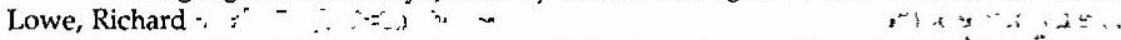

1999 Extracting Information from an Animation during Complex Visual Learning. European Journal of Psychology of Education, 14(2): 225-244.

MacDougall, David .

1997 The Visual in Anthropology. In Rethinking Visual Anthropology. Howard Morphy and Marcus Banks, eds. Pp. 276-295. New Haven and London: Yale University Press.

1998 Transcultural Cinema. Princeton, N.J.: Princeton University Press.

Marks, David F.

1990 On the Relationship between Imagery, Body, and Mind. In Imagery: Current Developments. P. J. Hampson, D. F. Marks, and J. T. E. Richardson, eds. Pp.1-38. London and New York: Routledge. 
Martin, Jay

1999 Must Justice Be Blind? The Challenge of Images into the Law. In Law and the Image. Costas Douzinas and Lynda Nead, eds. Pp. 19-35. Chicago: University of Chicago Press.

Martin, Maryanne, and Rachel Williams

1990 Imagery and Emotion: Clinical and Experimental Approaches. In Imagery: Current Developments. P. J. Hampson, D. F. Marks, and J. T. E. Richardson, eds. Pp. 268-306. London and New York: Routledge.

Mayer, Richard E.

1989 Systematic Thinking Fostered by Illustrations in Scientific Text. Journal of Educational Psychology, 81: 240-246.

Mayer, Richard E., and Richard B. Anderson

1992 The Instructive Animation: Helping Students Build Connections between Words and Pictures in Multimedia Learning. Journal of Educational Psychology, 81: 444-452.

McAdams, Dan P.

1993 The Stories We Live by: Personal Myths and the Making of the Self. New York: W. Morrow.

McLuhan, Marshall

1964 Understanding Media: The Extensions of Man. New York: McGraw-Hill.

Medina, Jennifer, and John Holl

20053 People Die in Fierce Collision of 2 S.U.V.'s. New York Times (Aug. 22): B3.

Messaris, Paul

1997 Visual Persuasion: The Role of Images in Advertising. Thousand Oaks, Calif., London, and New Delhi: Sage Publications.

Meyer, Philip N.

1994 Desperate for Love: Cinematic Influences upon a Defendant's Closing Argument to a Jury. Vermont Law Review, 18: 721-749.

Miller, Paul D.

2004 Rhythm Science. Cambridge, Mass, and London: MIT Press.

Mitchell, William J.

1986 Iconology: Image, Text, Ideology. Chicago: University of Chicago Press.

1994a Picture Theory: Essays on Verbal and Visual Representation. Chicago: University of Chicago Press.

1994b The Reconfigured Eye: Visual Truth in the Post-Photographic Era. Cambridge, Mass: MIT Press.

Mnookin, Jennifer L.

1998 The Image of Truth: Photographic Evidence and the Power of Analogy. Yale Journal of Law and the Humanities, 10 (Winter): 1-74.

Murray-Brown, Jeremy

1991 Video Ergo Sum. In Video Icons and Values. A. Olson, C. Parr, and D. Parr, eds. Pp. 17-32. Albany: State University of New York Press.

Nettel, Ana Laura

2005 The Power of Image and the Image of Power: The Case of Law. Word and Image, 21(2): 137-150.

Nisbett, Richard, and Lee Ross

1980 Human Inference: Strategies and Shortcomings of Social Judgment. Englewood Cliffs, N.J.: Prentice-Hall.

Nisson, Charles

1985 The Evidence or the Event? On Judicial Proof and the Acceptability of Verdicts. Haroard Law Review, 98: 1357-1392.

Ong, Walter J.

1982 Orality and Literacy: The Technologizing of the World. London and New York: Methuen.

Palmer, Steven E.

1999 Vision Science: Photons to Phenomenology. Cambridge, Mass.: MIT Press.

Pennington, Nancy, and Reid Hastie

1993 The Story Model for Juror Decision Making. In Inside the Juror: The Psychology of Juror Decision Making. Reid Hastie, ed. Pp. 192-224. Cambridge and New York: Cambridge University Press. 
Pink, Sarah

2001 Doing Visual Ethnography: Images, Medn, and Representation in Research. London and Thousand Oaks, Calif.: Sage Publications.

2004 Introduction. In Working Images: Visual Research and Representation in Ethnography. Sarah Pink, László Kürti, and A. Alfonso, eds. Pp. 1-13. London and New York: Routledge.

2006 The Future of Visual Anthropology. London and New York: Routledge.

Poggenpohl, Sharon Helmer, and Dietmar R. Winkler

1992 Diagrams as Tools for Worldmaking. Visible Language, 26(3): 253-269.

Posey, Amy J., and Lawrence S. Wrightsman

2005 Trial Consulting. Oxford and New York: Oxford University Press.

Post, Robert

1991 Law and the Order of Culture. Berkeley: University of Californa Press.

Postman, Neil

1985 Amusing Ourselves to Death: Public Discourse in the Age of Show Busmess. New York: Viking.

Potter, W. James

1988 Perceived Reality in Television Effects Research. Journal of Broadcasting and Electronic Media, 32(1): 23-41.

Prentice, Deborah A., Richard J. Gerrig, and D. Bailis

1997 What Readers Bring to the Processing of Fictional Texts. Psychonomic Bulletin and Review, 4(3): 416-420.

Prentice, Deborah A., and Richard J. Gerrig

1999 Exploring the Boundary between Fiction and Reality. In Dual-Process Theories in Social Psychology. Shelly Chaiken and Yaacov Trope, eds. Pp. 529-546. New York: Guilford Press.

Rawls, John

1993 Political Liberalism. New York: Columbia University Press.

Reeves, Byron, and Clifford Nass

1996 The Media Equation: How People Treat Computers, Television and New Media like Real People and Places. Stanford, Calif.: CSLI Publications; Cambridge: Cambridge University Press.

Ricoeur, Paul

1981 Hermeneutics and the Human Sciences: Essays on Language, Action, and Interpretation. John B.

Thomson, ed. and trans. Cambridge and New York: Cambridge University Press.

Ritchin, Fred

1999 In Our Own Image: The Coming Revolution in Photography. 2nd ed. New York: Aperture.

Ritter, G. Christopher

2004 Creating Winning Trial Strategies and Graphics. Chicago: American Bar Association Tort Trial and Insurance Practice section.

Robins, Kevin .

1996 Into the Image: Culture and Politics in the Field of Vision. London and New York: Routledge.

Rorty, Richard

2004 Foreword. In Nihilism and Emancipation: Ethics, Politics, and Law. Gianni Vattimo, ed.

Ruby, Jay Pp. xi-xx. New York: Columbia University Press.

2000 Picturing Culture: Explanations of Film and Anthropology. Chicago: University of Chicago Press.

Rusanow, Greta

2005 Knowledge Management and the Smarter Lawyer. New York: ALM Publishing.

Samuelson, Paula, and Suzanne Scotchmer

2002 The Law and Economics of Reverse Engineering. Yale Law Journal, 111: 1575-1663.

Sarat, Austin, and Thomas R. Kearns

1998 Law in the Domains of Culture. Ann Arbor: University of Michigan Press.

Sarbin, Theodore $R$.

1986 Narrative Psychology: The Storied Nature of Human Conduct. New York: Praeger.

Schafer, Roy

1992 Retelling a Life: Narration and Dialogue in Psychoanalysis. New York: Basic Books.

Schank, Roger, and Robert Abelson

1997 . Scripts Plans Goals and Understanding: An Inquiry into Human Knowledge Structures. Hillsdale,

N.J.: L. Erlbaum Associates; New York: Halstead Press Division of John Wiley and Sons. 
Sebeok, Thomas A.

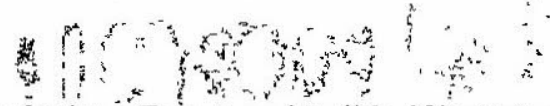

1994 Signs: An Introduction to Semiotics. Toronto and Buffalo, N.Y.: University of Toronto Press.

Seward, Barry, and Ann Marie

1997 Visual Intelligence: Perception, Image and Manipulation in Visual Communication. Albany: State University of New York Press.

Shapiro, Michael A., and Daniel G. McDonald

1992 I'm Not a Real Doctor, but I Play One in Virtual Reality: Implications of Virtual Reality for Judgments about Reality. Journal of Communication, 42(4): 94-114.

Sherman, Rorie

1993 And now the Power of Tape. National Law Journal, Feb. 8: A1.

Sherwin, Richard K.

1988 Dialects and Dominance: A Study of Rhetorical Fields in the Law of Confessions. University of Pennsylvania Law Review, 136: 729-849.

1994 Law Frames: Historical Truth and Narrative Necessity in a Criminal Case. Stanford Law Review, 47: 39-83.

1996 Picturing Justice: Images of Law and Lawyers in the Visual Media. University of San Francisco Law Review, 30: 891-901:

2000 When Law Goes Pop: The Vanishing Line between Law and Popular Culture. Chicago: University of Chicago Press.

2004 Law in Popular Culture. In The Blackwell Companion to Law and Society. Austin Sarat, ed. Malden, Mass. Blackwell Publishing.

2005 Anti-Oedipus, Lynch: Initiatory Rites and the Ordeal of Justice. In Law on the Screen. A. Sarat, L. Douglas, and M. Merrill Umphrey, eds. Pp 106-152. Stanford, Callf.: Stanford University Press.

Shin, Annys

2005 Newspaper Circulation Continues to Decline. BizReport, May 3. http://www.bizreport. com/news/8894.

Shweder, Richard

1991 Thinking through Cultures: Expeditions in Cultural Psychology. Cambridge, Mass.: Harvard University Press.

Siemer, Deanne C., and Frank D. Rothschild

2002 PowerPoint 2002 for Litigators. Notre Dame, Ind.: NITA.

Silbey, Susan S.

1992 Making a Place for Cultural Analyses of Law. Law and Social Inquiry, 17: 39-48.

Silbey, Susan S., and Sally E. Merry

1986 Mediator Settlement Strategies. Law and Policy, 8: 7-32.

Sim, Stuart

1998 The Icon Dictionary of Postmodern Thought. Cambridge: Icon.

Slattery, Karen

1990 Visual Information in Viewer Intrepretation and Evalutation of Television News Stories. Journal of Visual Literacy, 10(1): 26-44.

Smith, Barbara Herrnstein

1988 Contingencies of Value. Cambridge, Mass.: Harvard University Press.

Spence, Donald P.

1982 Narrative and Historical Truth: Meaning and Interpretation in Psychoanalysis. New York: W.W. Norton.

Spence, Gerry

1995 From Freedom to Slavery: The Rebirth of Tyranny in America. New York: St. Martin's Press.

Stachenfeld, Avi, and Christopher Nicholson

1996 Blurred Boundaries: An Analysis of the Close Relationship between Popular Culture and the Practice of Law. University of San Francisco Law Review, 30: 903-912.

Stallings, Robert A.

1990 Media Discourse and the Social Construction of Risk. Social Problems, 37: 80-95.

Stoller, Paul

1994 The Cinematic Griot: The Ethnography of Jean Rouch. Chicago: University of Chicago Press.

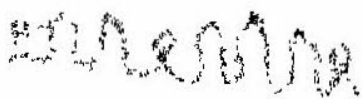




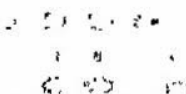

What Is Visual Knowledge, and What Is It Good for? 177

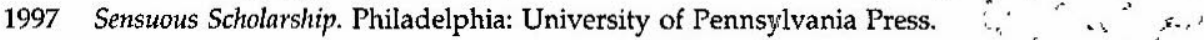

Struever, Nancy

1970 The Language of History in the Renaissance: Rhetoric and Historical Consciousness in Florentine Humanism. Princeton, N.J.: Princeton University Press.

Susskind, Richard is

2000 Transforming the Law: Essays on Technology, Justice and the Legal Marketplace. Oxford and New York: University Press.

Sweetser, Eve

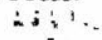

1990 From Etymology to Pragmatics: Metaphorical and Cultural Aspects of Semantic Structure. Cambridge and New York: Cambridge University Press.

Symposium.

2001 A New Legal Realism? Cultural Studies and the Law. Yale Journal of Law $\mathcal{E}$ the Humanties, 3: 3 .

Tarantino, John

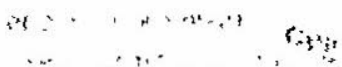

$\because+\cdots$

2004 Personal Injury Forms: Discovery and Settlement. Santa' Ana, Calif.: James Publishing.

Tufte, Edward R.

1983 The Visual Display of Quantitative Information. Cheshire, Ct.: Graphics Press.

1990 Envisioning Information. Cheshire, Ct.: Graphics Press.

1997 Visual Explanations. Cheshire, Conn.: Graphics Press. : :- :

Turkle, Sherry

1995 Life on the Screen: Identity in the Age of the Internet. New York: Simon \& Schuster.

Turner, Terence

1993 Anthropology and Multiculturalism: What Is Anthropology that Multiculturalists Should be Mindful of It? Cultural Anthropology, 8(4): 411-429.

Turner, Victor $W$.

1974 Dramas, Fields, and Metaphors: Symbolic Action in Human Society. Ithaca, N.Y.: Cornell University Press.

Tyler, Stephen A.

1986 Postmodern Ethnography: From Document of the Occult to Occult Document. In Writing Culture: The Poetics and Politics of Ethnography. James Clifford and George Marcus, eds.

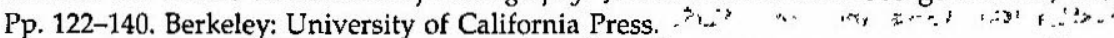

Weimann, Gabriel

2000 Communicating Unreality: Modern Media and the Reconstruction of Reality. Thousand Oaks, Calif.: Sage Publications. , , i, i, is , , :

Whelan, Darius

2005 The Bloody Sunday Tribunal. Exhibit at First International Conference on Visual Literacy, Cork, Ireland, April 14-15.

(Forthcoming 2007) The Bloody Sunday Tribunal. In'Visual Practices across the University. James Elkins, ed. Paderhorn (Germany): Wilhelm Fink Verlag.

i...

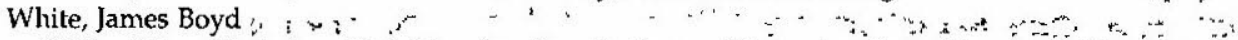

1984 When Words Lose Their Meaning: Constitutions and Reconstructions of Language, Character, and Community. Chicago: University of Chicago Press.

Wiggins, Elizabeth $\mathrm{C} . ;$ ? $i$,

2004 What We Know and What We Need to Know About Effects of Courtroom Technology. William and Mary Bill of Rights Journal, 12: 731-743. , : it:

Wiggins, E. C., M. A. Dunn, and G. Cort :-

2003 Federal Judicial Center Survey on Courtroom Technology, Federal Judicial Center. http:// www.fjc.gov.

[Wikipedia Contributors] a.':

2005 Adobe Photoshop. Wikipedia, The Free Encyclopedia. (Online).

2005 World Wide Web. Wikipedia, The Free Encyclopedia. (Online).

Williams, Raymond "

1980 Problems in Materialism and Culture: Selected Essays. London: Verso ${ }^{2}$,

Wittgenstein, Ludwig . ...

1958 Philosophical Investigations. 3rd ed. New York: Macmillan.'

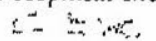


Wolfflin, Heinrich

1964 Renaissance and Baroque. Ithaca, N.Y.: Cornell University Press.

Yngvesson, Barbara

1989 Inventing Law in Local Settings: Rethinking Popular Legal Culture. Yale Law Journal, 98: 1689-1709.

Zakon, Robert H.

2005 Hobbes' Internet Timeline. Zakon Group LLC. http://www.zakon.org/robert/internet/ timeline.

\section{FILMOGRAPHY}

Avildsen, John G. 1976 Rocky. Los Angeles: United Artists.

Baker, Roy Ward 1958 A Night to Remember. Surrey, England: Pinewood Studios.

Buckley, Bill

1986 How to Use "Day-in-the-Life" Videos. Westport, Conn.: Professional Education Systems. 1986 How to Use Video Settlement Brochures. Westport, Conn.: Professional Education Systems.

Chase, David 1999 The Sopranos. New York: HBO Productions.

Cizek, Katerina, and Peter Wintonick 2002 Seeing Is Believing: Handicams, Human Rights, and the News. New York: First Run/Icarus Films.

Coppola, Francis Ford 1972 The Godfather. Los Angeles: Paramount Studies.

Stone, Oliver 1994 Natural Born Killers. Los Angeles. Lions Gate Films

Tarantino, Quentin 1994 Pulp Fiction. Los Angeles: Miramax Entertainment.

Wachowski, Andy, and Larry Wachowski 1999 The Matrix. Los Angeles: Warner Studios.

\section{COURT CASES}

Ashcroft v. The Free Speech Coalition, et al., 535 U.S. 234, 243 (2002).

Connecticut v. Skakel, No. FST CR00-135792T (Conn. Super. Ct., J.D. of Norwalk/Stamford) (June 3, 2002).

Connecticut v. Skakel, S.C. 16844 (Brief of the Defendant-Appellant, P. 60) (Nov. 24, 2003).

Hicks v. Arkansas, 327 Ark. 727 (1997).

Salazar v. Texas, 90 S.W.3d 330 (Tex. Crim. App. 2002).

Standard Chartered PLC v. Price Waterhouse, CV No. 88-34414 (Super. Ct., Maricopa Co., AZ, 1989), rev'd, 945 P.2d 317, 359 (Ariz. Ct. App. 1996).

Standard Chartered PLC v. Price Waterhouse, 1 CA-CV 93-0461,1 CA-CV 93-0442, (Consolidated) Court of Appeals of Arizona, Division One, Dept. A 190 Ariz. 6; 945 P. 2d 317; 1996 Ariz. App. LEXIS 243; 229 Ariz. Adv. Rep. 26 November 7, 1996.

State v. Swinton, Conn. 781 (2004).

United States of America v. David Hilton, 386 F.3d 13 (First Circuit, 2004).

Whelan, April 14-15, 2005. 